This document is the accepted manuscript version of the following article:

Shi, Z., \& Lothenbach, B. (2019). The role of calcium on the formation of alkalisilica reaction products. Cement and Concrete Research, 126, 105898 (12 pp.).

https://doi .org/10.1016/j. cemconres. 2019.105898

1

This manuscript version is made available under the CC-BY-NC-ND 4.0 1icense

http://creativecommons.org/1icenses/by-nc-nd/4.0/
2

5

\title{
The role of calcium on the formation of alkali-silica reaction products
}

2

* Corresponding author. Laboratory for Concrete \& Construction Chemistry, Swiss Federal Laboratories for Materials Science and Technology (Empa), 8600 Dübendorf, Switzerland. Email address: zhenguo.shi@empa.ch (Z.Shi). 
Abstract:

Predicting the conditions for alkali-silica reaction (ASR) had been difficult for several decades due to the lack of in-depth knowledge of the ASR products. In this study, thermodynamic data for the synthesized ASR products (i.e., K-shlykovite, Na-shlykovite and ASR-P1) at $80{ }^{\circ} \mathrm{C}$ are determined. The effect of the initial $\mathrm{Ca} / \mathrm{Si}$ ratio, from 0 to 0.5 , on the formation of ASR products at $80{ }^{\circ} \mathrm{C}$ is investigated for samples prepared with an initially fixed $\mathrm{K} / \mathrm{Si}$ or $\mathrm{Na} / \mathrm{Si}$ ratio of 0.5 . The results show that the amount of ASR products formed first increases and then decreases with increasing the initial $\mathrm{Ca} / \mathrm{Si}$ ratio. The reduced amount of ASR products at higher $\mathrm{Ca} / \mathrm{Si}$ ratio is accompanied by formation of $\mathrm{C}-\mathrm{S}-\mathrm{H}$, suggesting that a conversion of ASR products to $\mathrm{C}-\mathrm{S}-\mathrm{H}$ can occur at high $\mathrm{Ca} / \mathrm{Si}$ ratio. The solid phases and aqueous chemistry predicted by thermodynamic modelling agrees very well with the experimental results.

Keywords: alkali-silica reaction; shlykovite; ASR-P1; C-S-H; thermodynamic modelling 


\section{Introduction}

As one of the most challenging problems in concrete durability, alkali-silica reaction (ASR) has received significant attentions over the past 80 years since its discovery in 1940's by Stanton [1]. Because of its slow reaction, damages of concrete structures caused by ASR are usually observed after decades and are difficult to predict. In addition to the presence of reactive silica within aggregates, alkali hydroxide and water, which are essential to initiate ASR, the presence of calcium is also important for formation of ASR products.

Many studies have addressed the importance of calcium in ASR [2][3][4][5][6][7][8], however its role has been controversial for many years. Chatterji [9] suggested that the presence of a high amount of portlandite in the pore solution could form a semi-permeable layer around the aggregates, which allowed the hydroxyl ion penetration into the reactive silica grain but prevented the silica diffusion from the reactive site. Later, many other studies have confirmed that presence of calcium was essential for generating ASR expansion $[3][2][10][11][12][13][14]$ and that in the absence of calcium the reactive silica only dissolved and remained in the solution [3][2][8]. The important role of calcium on ASR was also recently demonstrated in alkali-activated low-Ca fly ash and metakaolin mortars, where much lower or no ASR expansion was observed, although a high alkali dosage was used for preparing the mortars [15].

In the presence of calcium, the dissolution of silica can be enhanced [6][16]. However, it was also reported that ASR gel without calcium could also form [17], and that high calcium content could reduce the expansion potential of ASR [18][14]. Furthermore, the calcium content in ASR products seems to increase with age, and calcium is often enriched in the ASR products found in the cement paste compared to those formed within reactive aggregates [19][20][13][21][22][23].

In order to better understand the formation conditions of ASR products in particular the role of calcium on ASR, thermodynamic modelling can be used as a powerful tool for predicting and understanding the reactions. Thermodynamic modelling has already been applied successfully to describe the C-S-H phase in hydrated cement depending on the $\mathrm{Ca} / \mathrm{Si}, \mathrm{Al} / \mathrm{Si}$ and $\mathrm{pH}$ [24][25]. First attempts at applying thermodynamic models to ASR have been made by Kim and Olek [26], and by Guthrie and Carey [27]. However, due to the lack of experimental solubility measurements and derived solubility products, Kim and Olek used the estimated solubilities for two hypothetical ASR products $\left(\mathrm{K}_{2} \mathrm{Ca}_{4} \mathrm{Si}_{6} \mathrm{O}_{17} \cdot 10.5 \mathrm{H}_{2} \mathrm{O}\right.$ and $\mathrm{Na}_{2} \mathrm{Ca}_{4} \mathrm{Si}_{6} \mathrm{O}_{17} \cdot 10.5 \mathrm{H}_{2} \mathrm{O}$ ) to describe the sequence of ASR [26], while Guthrie and Carey used 
the thermodynamic data for magadiite $\left(\mathrm{NaSi}_{7} \mathrm{O}_{14} \cdot 4.5 \mathrm{H}_{2} \mathrm{O}\right)$ and okenite $\left(\mathrm{CaSi}_{2} \mathrm{O}_{5} \cdot 2 \mathrm{H}_{2} \mathrm{O}\right)$ as surrogates for an alkali-silicate and a high calcium-silicate ASR products [27]. These calculations showed that it is in principle possible to predict the conditions for formation of ASR products, but also highlighted the need to use realistic chemical compositions and solubility products to predict the conditions for formation of ASR products.

Recently, two crystalline ASR products (K-shlykovite: $\mathrm{KCaSi}_{4} \mathrm{O}_{8}(\mathrm{OH})_{3} \cdot 2 \mathrm{H}_{2} \mathrm{O}$; Nashlykovite: $\mathrm{NaCaSi}_{4} \mathrm{O}_{8}(\mathrm{OH})_{3} \cdot 2.3 \mathrm{H}_{2} \mathrm{O}$ ) and one nano-crystalline ASR product (ASR-P1: $\left.\mathrm{K}_{0.52} \mathrm{Ca}_{1.16} \mathrm{Si}_{4} \mathrm{O}_{8}(\mathrm{OH})_{2.84} \cdot 1.5 \mathrm{H}_{2} \mathrm{O}\right)$ have been successfully synthesized [8]. The structures of the two synthesized crystalline ASR products were found to be very similar to the crystal structure of the natural mineral shlykovite $\left(\mathrm{KCa}\left[\mathrm{Si}_{4} \mathrm{O}_{9}(\mathrm{OH})\right] \cdot 3 \mathrm{H}_{2} \mathrm{O}\right)[28][23]$, which has a layered silicate structure with its $\mathrm{SiO}_{4}{ }^{4-}$ tetrahedron charge balanced by $\mathrm{K}^{+}$and $\mathrm{Ca}^{2+}$ in the main layer and by $\mathrm{H}^{+}$in the interlayer as shown in Fig. 1. For ASR-P1, a silicate sheet structure was also revealed [8]. Although the synthesis was conducted at much higher temperature compared to ASR in field concrete, it was found that the synthesized ASR products were very similar to those formed in concrete aggregates in term of chemical composition and structure [8][23], and almost identical to ASR products formed in concrete aggregate after concrete prism test at $60{ }^{\circ} \mathrm{C}$ according to Raman spectroscopy results [8]. Such strong similarity between the synthesized ASR products and ASR products formed in concrete aggregates support the use of synthesized ASR products for further understanding ASR. In particular, the successful syntheses of the large amount of these ASR products offer the possibility to determine their solubility products, which can be further implemented into thermodynamic modelling, and then used to predict the conditions for formation of ASR products, such as the role of calcium on ASR.

The aim of the present study is to experimentally determine the thermodynamic data for the ASR products (i.e., K-shlykovite, Na-shlykovite and ASR-P1) based on the samples synthesized at $80{ }^{\circ} \mathrm{C}$ after reaction for 90 days, and to investigate the effect of the initial $\mathrm{Ca} / \mathrm{Si}$ ratio of the mixtures on the ASR using thermodynamic modelling. The samples are investigated by X-ray diffraction analysis (XRD), ${ }^{29}$ Si MAS NMR and Fourier Transform Infrared Spectroscopy (FTIR) to identify the types of ASR products. 


\section{Materials and methods}

\subsection{Sample preparations}

Different samples with the same initial $\mathrm{K} / \mathrm{Si}$ or $\mathrm{Na} / \mathrm{Si}$ ratio of 0.5 and different initial $\mathrm{Ca} / \mathrm{Si}$ ratios of $0,0.1,0.2,0.3,0.4$ and 0.5 were synthesized by mixing designated quantities of amorphous $\mathrm{SiO}_{2}$ (hydrophilic silica, surface area $200 \mathrm{~m}^{2} / \mathrm{g}$, from EVONIK industries) with $\mathrm{CaO}$ (obtained by burning calcium carbonate for $12 \mathrm{~h}$ at $1000{ }^{\circ} \mathrm{C}$ ) and analytical $\mathrm{KOH}(\geq 85 \%$ $\mathrm{KOH}$ basis) or $\mathrm{NaOH}(\geq 99.9 \% \mathrm{NaOH}$ basis) pellet as shown in Table 1 and Fig 2. The relatively higher initial alkali/Si ratio was used in order to maintain the high $\mathrm{pH}$ of the solutions during reaction. The $\mathrm{Ca} / \mathrm{Si}$ ratios lower than 0.5 were selected, since calcium-silicate-hydrate will be the main reaction products at $\mathrm{Ca} / \mathrm{Si}$ above 0.5 . Three series of the samples were prepared: i) the samples containing $\mathrm{K}$ or (ii) containing $\mathrm{Na}$ as the alkalis source with high water contents (i.e., 60 - $100 \mathrm{~g}$ for each mixing), and (iii) samples containing only $\mathrm{K}$ as the alkali source with low water contents (i.e., $30-50 \mathrm{~g}$ for each mixing). For each experimental series, the water content is somewhat adjusted depending on the $\mathrm{Ca} / \mathrm{Si}$ ratios in order to be able to well disperse the materials during mixing. All samples were mixed in $100 \mathrm{~mL}$ high density polyethylene (PE-HD) bottles (from Semadeni AG) and equilibrated at $80{ }^{\circ} \mathrm{C}$ for 90 days. Afterwards, the liquid and solid phases were separated by filtration using paper filters with mesh size of $20 \mu \mathrm{m}$. Roughly $5 \mathrm{~mL}$ of the obtained solution were in addition immediately filtered with $0.45 \mu \mathrm{m}$ syringe filter for $\mathrm{pH}$ measurements and analysis of the solution compositions. The solids were rinsed first with approximately $50 \mathrm{~mL}$ of $1: 1$ water-ethanol solution and then with $50 \mathrm{~mL} 94 \%$ ethanol solution in the $\mathrm{N}_{2}$ filled glove box. The obtained solids were then vacuumed dried (ca. 200 mbar) for 3 days in desiccator filled with $\mathrm{N}_{2}$ and containing $\mathrm{CO}_{2}$ absorbent to prevent carbonation during storage.

\subsection{Methods}

\subsubsection{Experimental approaches}

The experimental approaches used in this study are the same as detailed in our previous work [8]. The solids obtained were analyzed by X-ray powder diffraction (XRD, PANalytical $\mathrm{X}$ 'pert Pro) with $\mathrm{CoK} \alpha$ radiation in a $\theta-\theta$ configuration. The samples were scanned with a step size of $0.017^{\circ} 2 \theta$ between 5 and $90^{\circ} 2 \theta$ with the $X^{\prime}$ Celerator detector during 2.5 hours. The ${ }^{29} \mathrm{Si}$ MAS NMR spectra were recorded on a Bruker Avance III NMR spectrometer at 79.5 MHz using a $7 \mathrm{~mm} \mathrm{CP} / \mathrm{MAS}$ probe. The following parameters were applied: $4500 \mathrm{~Hz}$ sample rotation rate, minimum of $10240 \mathrm{scans}, 30^{\circ}{ }^{1} \mathrm{H}$ pulse for $2.5 \mu \mathrm{s}, 20 \mathrm{~s}$ of relaxation delays, $\mathrm{RF}$ 
field strength of $33.3 \mathrm{kHz}$ during SPINAL64 proton decoupling. The ${ }^{29} \mathrm{Si}$ chemical shifts NMR spectra were externally referenced to tetramethylsilane (TMS) at $0.0 \mathrm{ppm}$. FTIR spectra were recorded on a Bruker Tensor 27 FT-IR spectrometer by transmittance between 600 and $4000 \mathrm{~cm}^{-1}$ with a resolution of $4 \mathrm{~cm}^{-1}$ on $\sim 3 \mathrm{mg}$ of powder of the synthesized ASR products.

The $\mathrm{pH}$ measurements were carried out as fast as possible after filtration using small fraction of the filtrated solution at room temperature around $23{ }^{\circ} \mathrm{C}$ with a Knick pH meter $(\mathrm{pH}-$ Meter 766) equipped with a Knick SE100 electrode. The electrode was calibrated with KOH or $\mathrm{NaOH}$ solutions of known concentrations to minimize the alkali error caused by the presence of high $\mathrm{K}$ and $\mathrm{Na}$ concentrations [29]. Another part of the filtrated solution was diluted by $1: 10,1: 100$ and 1:1000 with MilliQ water and used for ionic chromatography (IC) analysis. The bulk chemical compositions of the obtained solids were calculated from mass balance calculations based on the chemical compositions of the starting materials and the measured elemental concentrations of the solution at equilibrium by taking into account the water bound in solids measured by thermogravimetric analysis (TGA). The impurities of $\mathrm{KOH}$ pellet and $10 \%$ analytical error of IC measurements have been taken into account in the mass balance calculations.

\subsubsection{Thermodynamic modelling}

Thermodynamic modelling was performed using the Gibbs free energy minimization software GEMS v3.3 [30][31]. It is a general-purpose geochemical modelling program which can be used to calculate the thermodynamic equilibrium and predict the composition of a system composed of aqueous, solid and gaseous phases at the temperature and pressure of interest by minimizing the Gibbs free energy of the system. The calculations were carried out using the PSI/Nagra general thermodynamic database [32], and the Cemdata18 database [33] to calculate the elemental concentration in solution and solid phases precipitated at $80{ }^{\circ} \mathrm{C}$. For C-S-H, the CNSH model developed by Myers et al was used [34]. In addition, a Kendmember was also introduced with a stability $0.5 \mathrm{log}$ units lower than the Na-endmember as detailed in Table 2.

Solubility data for the model ASR products (Na-shlykovite, K-shlykovite and ASR-P1) are obtained experimentally in this study from both precipitation and dissolution experiments at $80{ }^{\circ} \mathrm{C}$. Based on the chemical composition of the solid and the measured aqueous concentrations, solubility products were calculated for the following three different ASR products: 
K-shlykovite: $\mathrm{K}_{\mathrm{S} 0}\left(\mathrm{KCaSi}_{4} \mathrm{O}_{8}(\mathrm{OH})_{3} \cdot 2 \mathrm{H}_{2} \mathrm{O}\right)=\frac{\left\{\mathrm{K}^{+}\right\} \cdot\left\{\mathrm{Ca}^{2+}\right\} \cdot\left\{\mathrm{SiO}_{2}^{0}\right\}^{4} \cdot\left\{\mathrm{OH}^{-}\right\}^{3} \cdot\left\{\mathrm{H}_{2} \mathrm{O}\right\}^{2}}{\left\{\mathrm{KCaSi}_{4} \mathrm{O}_{8}(\mathrm{OH})_{3} \cdot 2 \mathrm{H}_{2} \mathrm{O}\right\}}$

Na-shlykovite: $\mathrm{K}_{\mathrm{S} 0}\left(\mathrm{NaCaSi}_{4} \mathrm{O}_{8}(\mathrm{OH})_{3} \cdot 2.3 \mathrm{H}_{2} \mathrm{O}\right)=\frac{\left\{\mathrm{Na}^{+}\right\} \cdot\left\{\mathrm{Ca}^{2+}\right\} \cdot\left\{\mathrm{SiO}_{2}^{0}\right\}^{4} \cdot\left\{\mathrm{OH}^{-}\right\}^{3} \cdot\left\{\mathrm{H}_{2} \mathrm{O}\right\}^{2.3}}{\left\{\mathrm{NaCaSi}_{4} \mathrm{O}_{8}(\mathrm{OH})_{3} \cdot 2.3 \mathrm{H}_{2} \mathrm{O}\right\}}$

ASR-P1: $\mathrm{K}_{\mathrm{S} 0}\left(\mathrm{~K}_{0.52} \mathrm{Ca}_{1.16} \mathrm{Si}_{4} \mathrm{O}_{8}(\mathrm{OH})_{2.84} \cdot 1.5 \mathrm{H}_{2} \mathrm{O}\right)=\frac{\left\{\mathrm{K}^{+}\right\}^{0.52} \cdot\left\{\mathrm{Ca}^{2+}\right\}^{1.16} \cdot\left\{\mathrm{SiO}_{2}^{0}\right\}^{4} \cdot\left\{\mathrm{OH}^{-}\right\}^{2.84} \cdot\left\{\mathrm{H}_{2} \mathrm{O}\right\}^{1.5}}{\left\{\mathrm{~K}_{0.52} \mathrm{Ca}_{1.16} \mathrm{Si}_{4} \mathrm{O}_{8}(\mathrm{OH})_{2.84} \cdot 1.5 \mathrm{H}_{2} \mathrm{O}\right\}}$

\{\} denotes the activity of the species calculated by GEMS from the measured concentrations of the equilibrium solution. The activity of a pure solid phase is equal to 1 by definition. Activities (dimensionless) of dissolved species are related to the molal concentrations [ ] (in $\left.\mathrm{mol} / \mathrm{kg} \mathrm{H} \mathrm{H}_{2} \mathrm{O}\right)$ by a correction term, i.e., the activity coefficient $\left(\gamma_{i}\right.$, dimensionless), which can be expressed as $\left\{K^{+}\right\}=\gamma_{K^{+}}\left[K^{+}\right]$for instance for $K^{+} ;\left[K^{+}\right]$is the molal concentration in $\mathrm{mol} / \mathrm{kg} \mathrm{H} \mathrm{H}_{2} \mathrm{O}$. The activity coefficient $\left(\gamma_{i}\right)$ of the relevant species were calculated using the extended Debye-Hückel equation with the common ion-size parameter $a_{i}$ of $3.67 \AA$ for $\mathrm{KOH}$ and $3.31 \AA$ for $\mathrm{NaOH}$ solutions and the common third parameter $b_{y}$ according to the equation: $\log \gamma_{i}=\frac{-A_{y} z_{i}^{2} \sqrt{I}}{1+B_{y} a_{i} \sqrt{I}}+b_{y} I$, where $z_{i}$ is the charge of species $i, I$ is the effective molal ionic strength, $b_{y}$ is a semi-empirical parameter $(\sim 0.123$ for $\mathrm{KOH}$ and $\sim 0.098$ for $\mathrm{NaOH}$ electrolyte at $25{ }^{\circ} \mathrm{C}$ ), and $A_{y}$ and $B_{y}$ are $\mathrm{P}, \mathrm{T}$-dependent coefficients. For uncharged species, the above equation reduces to $\log \gamma_{i}=b_{y} I$. This extended Debye-Hückel activity correction is applicable up to approx. $1 \mathrm{M}$ ionic strength [35].

\section{Results and discussion}

\subsection{Chemical compositions of the synthesized ASR products}

The solid phase compositions of these samples determined by SEM/EDX, mass balance calculations and TGA measurements are summarized in Table 3. Compared to the SEM/EDX data, the $\mathrm{Ca} / \mathrm{Si}, \mathrm{Na} / \mathrm{Si}$ and $\mathrm{K} / \mathrm{Si}$ ratios calculated from mass balance, based on the initial compositions and the measured concentrations of solutions, give the total bulk composition of the ASR product(s) and any other solid present, while SEM/EDX data are better able to capture the composition of the of the solid of interest. The SEM/EDX data show negligible amounts of $\mathrm{Na}$ in the ASR-P1. Comparison of the results between SEM/EDX and mass balance suggests that the solids also contain C-S-H and/or unreacted silica in addition to the different ASR products. The $\mathrm{Ca} / \mathrm{Si}, \mathrm{K} / \mathrm{Si}$ and $\mathrm{H}_{2} \mathrm{O} / \mathrm{Si}$ ratios measured by SEM/EDX and TGA for the synthesized K-shlykovite agree within the error of measurements with the chemical composi- 
tion of the natural shlykovite: $\mathrm{KCa}\left[\mathrm{Si}_{4} \mathrm{O}_{9}(\mathrm{OH})\right] \cdot 3 \mathrm{H}_{2} \mathrm{O}$ determined by [28]. For Na-shlykovite the same $\mathrm{Ca} / \mathrm{Si}$ and alkali/Si ratios are used, as structural refinement of the XRD data indicated the absence of any additional cations in the interlayer of Na-shlykovite [8]. For the nanocrystalline ASR-P1, $\mathrm{K}_{0.13} \mathrm{Ca}_{0.29} \mathrm{SiO}_{2}(\mathrm{OH})_{0.71} \cdot 0.375 \mathrm{H}_{2} \mathrm{O}$, the data from SEM/EDX and TGA are used.

\subsection{Solubility products}

The solubility products for K-shlykovite, Na-shlykovite and ASR-P1 are first calculated based on the data collected from precipitation experiments (See Table 4). Based on the selected chemical composition given in Table 3 and the measured aqueous concentrations, solubility products for the different ASR products are calculated. However, the calculated solubility data from the precipitation experiments show a significant scatter, which are related to very high silicon concentrations up to $900 \mathrm{mM}$ and the relatively high temperature, since the present thermodynamic databases [32][33] cannot precisely describe the aqueous polynuclear silica complexes formed at high silica concentrations. In addition, temperature parameters are missing to extrapolate the stability of aqueous polynuclear silica species from ambient temperature to $80{ }^{\circ} \mathrm{C}$, indicating the need for a better description of aqueous silica species at high concentrations of Si and temperatures.

Due to the problems caused by the high silicon concentration in the precipitation experiments, the solubility products of ASR products are also measured from dissolution experiments by re-dispersing $0.6 \mathrm{~g}$ dried samples (i.e., $\mathrm{SNC}$ : Na-shlykovite, $\mathrm{SK}_{0.35} \mathrm{~N}_{0.15} \mathrm{C}$ : ASR-P1 and SKC\#: K-shlykovite, see Table 4) from a previous study [8] in $10 \mathrm{~g}$ water at $80{ }^{\circ} \mathrm{C}$ for 1 month. Afterwards, the samples were filtrated. The $\mathrm{pH}$ and composition of the solutions were measured as shown in Table 4. The composition of the solids after dissolution and filtration was verified with FTIR measurements as shown in Fig 3. The results show that the part of the synthesized ASR products remains after re-dispersion in $10 \mathrm{~g}$ water. Na-shlykovite is partially dissolved and some C-S-H is formed. The formation of ASR-P1 is observed for the sample initially only containing K-shlykovite, suggesting that a conversion of K-shlykovite to ASR-P1 can take place at high water contents as also shown in Fig 4. Therefore, the solubility products for both K-shlykovite and ASR-P1 can be obtained from the SKC\# sample.

The solubility products of Na-shlykovite and K-shlykovite derived from the dissolution experiments only are used for thermodynamic modelling, while for ASR-P1 the mean value from the data obtained in dissolution experiments (Table 4) and in the precipitation experiments in the later section with the concentration of Si less than $100 \mathrm{mM}$ is calculated as sum- 
marized in Table 5. The observation of a systematic difference in $\log \mathrm{K}_{\mathrm{S}_{0}}$ between precipitation and dissolution experiments suggests that the near-equilibrium conditions have been reached in both kinds of experiments.

\subsection{Phase assemblages}

The XRD patterns for the solid samples containing $\mathrm{K}$ and $\mathrm{Na}$ with high and low water contents are shown in Fig. 4. For the reference samples $\left(\mathrm{SKC}_{0}\right.$ and $\left.\mathrm{SNC}_{0}\right)$ without calcium, only the unreacted amorphous silica is observed as shown by the presence of a broad peak at $26^{\circ} 2 \theta$. Clearly no alkali-silicate gel seems to be formed in the absence of calcium, in contrast to observations reported in literature that alkali-silicate gel without calcium could form during ASR [17]. High concentrations of silicon and alkali are found in the equilibrium solution indicating a partial dissolution of the amorphous silica (see Table 6).

For the K-containing samples, the addition of a small amount of calcium for the samples with initial $\mathrm{Ca} / \mathrm{Si}$ ratio of 0.1 and 0.2 results in the formations of poorly crystalline and crystalline reaction products for the samples with high and low water contents, respectively. Traces of the same crystalline product are also observed in the $\mathrm{SKC}_{0.2}$ sample with high water content by comparing their XRD patterns in Fig 4a and Fig 4b, which is also further confirmed by ${ }^{29} \mathrm{Si}$ MAS NMR results shown in Fig 5. For the Na-containing samples in Fig 4c, another crystalline ASR product is observed with increasing the initial $\mathrm{Ca} / \mathrm{Si}$ ratio, and its intensity reaches maximum at $\mathrm{Ca} / \mathrm{Si}$ of 0.2 and 0.3 . Traces of Na-shlykovite are also observed in the $\mathrm{SNC}_{0.1}$ sample as well as a minor unidentified phase. The crystalline phases observed in both $\mathrm{K}$ and $\mathrm{Na}$ samples correspond to K-shlykovite and Na-shlykovite reported in previous studies [28][8], which have similar structure to the ASR products formed in the field and in concrete subjected to higher temperature for accelerated ASR testing [8][23]. The poorly crystalline ASR product has been labeled previously as ASR-P1 [8] and contains somewhat more Ca than shlykovite. With the further increase of the $\mathrm{Ca} / \mathrm{Si}$ ratios for the $\mathrm{SKC}_{0.3}$ and $\mathrm{SKC}_{0.4}$ samples, only the nano-crystalline ASR product (ASR-P1) is observed. At the highest $\mathrm{Ca} / \mathrm{Si}$ ratio of 0.5, ASR-P1 co-exists with C-S-H in $\mathrm{SKC}_{0.5}$ samples at high and low water contents. For Na-containing samples, at higher $\mathrm{Ca} / \mathrm{Si}$ ratio of 0.4 , the intensity of the XRD pattern related to the Na-shlykovite is significantly reduced, accompanied by the formation of C-S-H. At Ca/Si equal to 0.5 only C-S-H is present and no Na-shlykovite is observed. This sequence is similar to what has been observed for K-shlykovite and ASR-P1 as discussed above. In contrast to Kcontaining samples with high water contents, no ASR-P1 or its analogue is observed in the 
Na-containing samples, indicating that ASR-P1 cannot be formed in the absence of K. Nashlykovite is observed at higher water contents, again in contrast to the conversion of Kshlykovite into ASR-P1 at high water contents.

The results in Fig 4 underline that calcium is necessary to form ASR products in line with many other studies $[2][3][4][6][7]$ and also that too much calcium destabilizes the ASR products to C-S-H as also reported previously [5][6]. Moreover, K-shlykovite is found to be less stable at high calcium and high water contents than ASR-P1. The evidence of conversion of the crystalline ASR product to an amorphous one and further to C-S-H phase shows some similarities to the observations in ASR affected concrete samples, where the ASR products found in paste have higher content of $\mathrm{Ca}$ than those found within reactive aggregate $[20][19][21][23][22]$.

\subsection{Solution chemistry}

The measured concentrations of $\mathrm{Ca}, \mathrm{K}$ (or $\mathrm{Na}$ ) and $\mathrm{Si}$ in the supernatants together with the $\mathrm{pH}$ values (measured at $23{ }^{\circ} \mathrm{C}$ ) for the $\mathrm{K}$ - and Na-containing samples with high and low water contents are shown in Table 6 and Fig 6 . The Ca concentrations are generally higher at high $\mathrm{Ca} / \mathrm{Si}$ ratio for all samples with both high and low water contents. Nearly no $\mathrm{Ca}$ is present in the equilibrium solution for the K-containing samples with $\mathrm{Ca} / \mathrm{Si}$ ratio of 0.1 and 0.2 , where the formation of K-shlykovite is observed from XRD patterns as shown in Fig 4a,b. Note that a low amount of $\mathrm{Ca}(0.036 \mathrm{mM} \mathrm{Ca}$, from impurities in the starting materials $)$ is measured in the sample $\mathrm{SNC}_{0}$, where no $\mathrm{CaO}$ had been added during the synthesis. Very low Ca concentrations are observed for the Na-containing samples with $\mathrm{Ca} / \mathrm{Si}$ ratio of 0.1 and 0.2 , indicating that all $\mathrm{Ca}$ has reacted to form Na-shlykovite and other phase(s) as seen from the $\mathrm{XRD}$ results in Fig 4c. At a $\mathrm{Ca} / \mathrm{Si}$ ratio of 0.3 , Ca concentration is slightly increased for all the samples, which could indicate the presence of another phase, most likely C-S-H, together with ASR-P1 or Na-shlykovite, although C-S-H is not clearly seen from the XRD results in Fig 4. With the increase of the $\mathrm{Ca} / \mathrm{Si}$ ratio, a decrease of concentration for both $\mathrm{K}$ (or $\mathrm{Na}$ ) and Si together with increase of $\mathrm{pH}$ are observed; the concentrations tend to reach a constant value at $\mathrm{Ca} / \mathrm{Si}$ ratio $\geq 0.4$. The $\mathrm{Si}$ concentration, which is higher at lower $\mathrm{Ca} / \mathrm{Si}$, is observed to reduce faster than $\mathrm{K}$ concentration with increasing the $\mathrm{Ca} / \mathrm{Si}$ ratio.

For the K-containing samples, the $\mathrm{K}$ and $\mathrm{Si}$ concentrations are lower for samples with higher water contents due to the dilution effect. However, the Ca concentration is an order of magnitude higher for samples with higher water contents than the samples with lower water 
contents due to the common ion effect between $\mathrm{Ca}, \mathrm{Si}$ and $\mathrm{K}$ as also observed in another study [36]. Despite the differences in the measured concentrations between samples with high and low water contents as shown in Fig 6, it is interesting to see that their $\mathrm{pH}$ values at the same $\mathrm{Ca} / \mathrm{Si}$ ratio are very similar. This observation suggests that the effect of water content on the solution concentrations and formation of different types of ASR products is not affected by the $\mathrm{pH}$ of the equilibrium solution.

Overall, the $\mathrm{Ca}, \mathrm{Na}$ and $\mathrm{Si}$ concentrations are lower for Na-containing samples than for the corresponding K-containing samples with similar water contents indicating more uptake of $\mathrm{Na}$ than $\mathrm{K}$ in the solids, consistent with previous observations [8]. The Ca concentrations are two orders of magnitude lower for the Na-containing samples than for the corresponding K-containing samples, indicating a higher stability of Na-shlykovite than of K-shlykovite and ASR-P1. Similar trends are also observed for the measured $\mathrm{pH}$ values, although the values are lower for the Na-containing samples than for the K-containing samples. The trends observed for the changes in $\mathrm{Ca}, \mathrm{K}$ (or $\mathrm{Na}$ ) and $\mathrm{Si}$ concentrations together with the changes of the measured $\mathrm{pH}$ values with increasing $\mathrm{Ca} / \mathrm{Si}$ ratio are found to be similar to those for $\mathrm{C}-(\mathrm{A})-\mathrm{S}-\mathrm{H}$ samples [37][25][38].

\subsection{Thermodynamic modelling of ASR}

Based on the thermodynamic data derived for K-shlykovite, Na-shlykovite and ASR-P1 at $80^{\circ} \mathrm{C}$, the changes in equilibrium concentrations and $\mathrm{pH}$ of the equilibrium solutions, together with the phase assemblages with increasing $\mathrm{Ca} / \mathrm{Si}$ ratio are predicted by thermodynamic modelling as shown in Fig 7. For comparison, the experimental data from Table 6 is also plotted in the same figure. Overall, the thermodynamic modelling results show similar trends for the changes in equilibrium concentrations and $\mathrm{pH}$ values with increasing $\mathrm{Ca} / \mathrm{Si}$ ratio as the experimental observations: (i) $\mathrm{Ca}$ concentration and $\mathrm{pH}$ values are higher at high $\mathrm{Ca} / \mathrm{Si}$ ratio, whereas $\mathrm{K}$ (or Na) and Si concentrations are lower; (ii) low K (or $\mathrm{Na}$ ) and Si concentration at high water contents; (iii) similar $\mathrm{pH}$ values between the two series K-containing samples at the same $\mathrm{Ca} / \mathrm{Si}$ ratio but different water contents. However, also some discrepancies are observed between the calculated and measured data, such as different $\mathrm{pH}$ and $\mathrm{Si}$ concentrations in particular at low $\mathrm{Ca} / \mathrm{Si}$ ratios when the $\mathrm{Si}$ concentration is high. This apparent discrepancy is thought to be related to poorly described aqueous polynuclear silica complexes at high $\mathrm{Si}$ concentration and temperature, which make thermodynamic modelling less accurate. 
In addition to the equilibrium concentrations, also the solid phases are predicted as shown in Fig 7. The results show that formation of K-shlykovite is only predicted for the Kcontaining samples with lower water contents and lower $\mathrm{Ca} / \mathrm{Si}$ ratio in agreement with the experimental observations. At high water contents, ASR-P1 is the only ASR product predict by thermodynamic modelling, while for the K-containing samples with lower water contents, ASR-P1 is formed instead of $\mathrm{K}$-shlykovite at high $\mathrm{Ca} / \mathrm{Si}$ ratio.

Na-shlykovite is the only ASR product that can be predicted for Na-containing samples, no K-shlykovite and ASR-P1 are predicted due to the absence of K. The calculations also show that the amount of Na-shlykovite increases and then decreases with increasing $\mathrm{Ca} / \mathrm{Si}$ ratio. The maximum amount of Na-shlykovite is calculated for a $\mathrm{Ca} / \mathrm{Si}$ ratio of 0.2 , where also the highest intensity of the XRD pattern is observed (see Fig 4).

The formation of C-S-H starts to be predicted when the $\mathrm{Ca} / \mathrm{Si}$ ratio is above 0.2 with low quantities (which are too low to be observed from XRD pattern); the amount of C-S-H increases with the increase of $\mathrm{Ca} / \mathrm{Si}$ ratio. These predictions are nicely in agreement with the observation of $\mathrm{C}-\mathrm{S}-\mathrm{H}$ at $\mathrm{Ca} / \mathrm{Si}$ ratio of 0.5 from XRD patterns as shown in Fig 4 and ${ }^{29} \mathrm{Si}$ NMR results as shown in Fig 5.

\subsection{Bulk chemical compositions of the obtained solids}

Based on the initial compositions of the mixtures and the measured equilibrium concentrations, the bulk compositions of the solids for the K-containing samples with both high and low water contents and for the Na-containing samples with high water content only are calculated by mass balance as summarized in Table 6 and plotted in Fig 8. For comparison, the selected chemical compositions of the K-shlykovite, ASR-P1 and Na-shlykovite as shown in Table 3 are also plotted in the same figure. The results show that the bulk $\mathrm{Ca} / \mathrm{Si}$ ratio of the obtained solids increases with the increase of the initial $\mathrm{Ca} / \mathrm{Si}$ ratio. The higher values of the $\mathrm{Ca} / \mathrm{Si}$ ratio than those of K-shlykovite, ASR-P1 and Na-shlykovite suggest that additional C$\mathrm{S}-\mathrm{H}$ is also formed in these samples, which further support the co-precipitation of C-S-H with ASR products as observed from XRD results (Fig 4), and also predicted by thermodynamic modelling (Fig 7).

In contrast to the $\mathrm{Ca} / \mathrm{Si}$ ratio, the $\mathrm{K} / \mathrm{Si}$ ratio is found to increase and then to decrease with increasing $\mathrm{Ca} / \mathrm{Si}$ ratio for the $\mathrm{K}$-containing samples with high water contents. The decreasing of the $\mathrm{K} / \mathrm{Si}$ ratio is observed for the samples at $\mathrm{Ca} / \mathrm{Si}$ over 0.5 , where also $\mathrm{C}-\mathrm{S}-\mathrm{H}$ is formed (Fig 4). This observation provides a direct evidence for the phenomenon called "alkali recy- 
cling”, as identified in ASR-affected concrete structures [13][12]. This is also in agreement with the amount of solid phases predicted by thermodynamic modelling in Fig 7, which is decreasing for ASR products and increasing for $\mathrm{C}-\mathrm{S}-\mathrm{H}$ with increasing $\mathrm{Ca} / \mathrm{Si}$ ratio, as the maximum alkali binding capacity of C-S-H is about 0.25 [39]. The alkali uptake on C-S-H is lower at higher $\mathrm{Ca} / \mathrm{Si}$ ratio. It also suggested that the recycling of alkalis will continuously contribute to the dissolution of the remaining reactive silica in concrete aggregate and generate further ASR [13][12]. In the model system of this work, no further ASR is expected at high $\mathrm{Ca} / \mathrm{Si}$ with alkali recycling, since all the reactive silica has reacted as observed from ${ }^{29} \mathrm{Si}$ MAS NMR results (see Fig 5).

Moreover, in concrete alkali solution is available to initiate the dissolution of reactive silica within the aggregate; Ca may participate later or at the same time depending on the availability. Thus, at certain places within aggregates, Ca may not be available which will influence the formation of Ca-containing ASR products. In contrast, during the synthesis of the laboratory ASR products, all ingredients such as amorphous silica, alkali solution and $\mathrm{CaO}$ are available for reaction from the beginning of synthesis. Both systems show the importance of availability of $\mathrm{Ca}$. This is supported by the formation of crystalline ASR products, amorphous ASR products and C-S-H depending on Ca availability in both model systems in this study and in concrete along the vein of aggregates extended to cement paste as reported in literature [20][19][21][23] as illustrated in Fig 9.

\section{Conclusions}

In this study, the role of $\mathrm{Ca}$ on the formation of ASR products has been investigated for samples containing either $\mathrm{K}$ or $\mathrm{Na}$ as the alkali source. For this purpose, samples with $\mathrm{Ca} / \mathrm{Si}$ ratios of $0,0.1,0.2,0.3,0.4$ and 0.5 with constant $\mathrm{K} / \mathrm{Si}$ or $\mathrm{Na} / \mathrm{Si}$ ratio of 0.5 were prepared. The effect of water content has also been investigated for the K-containing samples. Thermodynamic data for three types of ASR products (i.e., K-shlykovite, Na-shlykovite and ASR-P1) have been determined and used to predict the effect of $\mathrm{Ca} / \mathrm{Si}$ on the formation of ASR products. Based on the results and discussions, the following conclusions can be drawn:

(1) Calcium plays a significant role in formation of ASR products in both K- and Nacontaining samples. Amorphous silica is only substantially consumed in presence of Ca.

(2) Crystalline ASR products are favorably formed at low initial $\mathrm{Ca} / \mathrm{Si}$ ratio at $80{ }^{\circ} \mathrm{C}$, i.e., $\mathrm{Ca} / \mathrm{Si}=0.1$ to 0.2 for $\mathrm{K}$-shlykovite, and $\mathrm{Ca} / \mathrm{Si}=0.2$ to 0.4 for Na-shlykovite. $\mathrm{K}$ - 
shlykovite is replaced by nano-crystalline ASR-P1 at high water contents or at $\mathrm{Ca} / \mathrm{Si}$ ratios over 0.3.

(3) At high $\mathrm{Ca} / \mathrm{Si}$ ratio of 0.5 , ASR products are destabilized to C-S-H. This sequence resembles those observed in ASR affected concrete structures [20][19][21][23][22], where crystalline ASR products are usually observed within aggregates with limited amount of

\section{Acknowledgements}

The authors would like to thank the SNF Sinergia: Alkali-silica reaction in concrete (ASR), grant number CRSII5_17108. The EMPAPOSTDOCS-II programme has received funding from the European Union's Horizon 2020 research and innovation programme under the Marie Skłodowska-Curie grant agreement number 754364. Luigi Brunetti and Bin Ma are acknowledged for IC measurement of the solutions, and Daniel Rentsch for acquiring the ${ }^{29} \mathrm{Si}$ 
430 MAS NMR spectra. Andreas Leemann is acknowledged for SEM/EDX analysis and helpful 431 discussions. The thanks are extended also to Guoqing Geng for helpful discussions. 


\section{References}

[1] T.E. Stanton, Influence of cement and aggregate on concrete expansion, Eng. NewsRecord. (1940).

[2] L. Struble, S. Diamond, Unstable swelling behaviour of alkali silica gels, Cem. Concr. Res. 11 (1981) 611-617.

[3] L.J. Struble, S. Diamond, Swelling properties of synthetic alkali silica gels, J. Am. Ceram. Soc. 64 (1981) 652-655.

[4] R.F. Bleszynski, M.D.A. Thomas, Microstructural studies of alkali-silica reaction in fly ash concrete immersed in alkaline solutions, Adv. Cem. Based Mater. 7 (1998) 66-78.

[5] X. Hou, L.J. Struble, R.J. Kirkpatrick, Formation of ASR gel and the roles of CSH and portlandite, Cem. Concr. Res. 34 (2004) 1683-1696.

[6] A. Leemann, G. Le Saout, F. Winnefeld, D. Rentsch, B. Lothenbach, Alkali-silica reaction: the influence of calcium on silica dissolution and the formation of reaction products, J. Am. Ceram. Soc. 94 (2011) 1243-1249.

[7] A. Leemann, T. Katayama, I. Fernandes, M.A.T.M. Broekmans, Types of alkaliaggregate reactions and the products formed, Proc. Inst. Civ. Eng. Mater. 169 (2016) $128-135$.

[8] Z. Shi, G. Geng, A. Leemann, B. Lothenbach, Synthesis, characterization, and water uptake property of alkali-silica reaction products, Cem. Concr. Res. 121 (2019) 58-71.

[9] S. Chatterji, The role of $\mathrm{Ca}(\mathrm{OH})_{2}$ in the breakdown of Portland cement concrete due to alkali-silica reaction, Cem. Concr. Res. 9 (1979) 185-188.

[10] L.S.D. Glasser, N. Kataoka, On the role of calcium in the alkali-aggregate reaction, Cem. Concr. Res. 12 (1982) 321-331.

[11] S. Chatterji, A.D. Jensen, N. Thaulow, P. Christensen, Studies of alkali-silica reaction. Part 3. Mechanisms by which $\mathrm{NaCl}$ and $\mathrm{Ca}(\mathrm{OH})_{2}$ affect the reaction, Cem. Concr. Res. 16 (1986) 246-254.

[12] H. Wang, J.E. Gillott, Mechanism of alkali-silica reaction and the significance of calcium hydroxide, Cem. Concr. Res. 21 (1991) 647-654.

[13] M. Thomas, The role of calcium hydroxide in alkali recycling in concrete, Mater. Sci. Concr. Spec. (2001) 225-236. 
[14] A.G. Vayghan, F. Rajabipour, J.L. Rosenberger, Composition-rheology relationships in alkali-silica reaction gels and the impact on the Gel's deleterious behavior, Cem. Concr. Res. 83 (2016) 45-56.

[15] Z. Shi, C. Shi, J. Zhang, S. Wan, Z. Zhang, Z. Ou, Alkali-silica reaction in waterglassactivated slag mortars incorporating fly ash and metakaolin, Cem. Concr. Res. 108 (2018) 10-19.

[16] T. Kim, J. Olek, Chemical Sequence and Kinetics of Alkali - Silica Reaction Part I. Experiments, J. Am. Ceram. Soc. 97 (2014) 2195-2203.

[17] X.-D. Cong, R.J. Kirkpatrick, S. Diamond, 29Si MAS NMR spectroscopic investigation of alkali silica reaction product gels, Cem. Concr. Res. 23 (1993) 811823.

[18] T.C. Powers, H.H. Steinour, An interpretation of some published researches on the alkali-aggregate reaction Part 1-The chemical reactions and mechanism of expansion, in: J. Proc., 1955: pp. 497-516.

[19] T. Knudsen, N. Thaulow, Quantitative microanalyses of alkali-silica gel in concrete, Cem. Concr. Res. 5 (1975) 443-454.

[20] N. Thaulow, U.H. Jakobsen, B. Clark, Composition of alkali silica gel and ettringite in concrete railroad ties: SEM-EDX and X-ray diffraction analyses, Cem. Concr. Res. 26 (1996) 309-318.

[21] T. Katayama, ASR gels and their crystalline phases in concrete-universal products in alkali-silica, alkali-silicate and alkali-carbonate reactions, in: Proc. 14th Int. Conf. Alkali Aggreg. React. (ICAAR), Austin, Texas, 2012: pp. 20-25.

[22] A. Leemann, Raman microscopy of alkali-silica reaction (ASR) products formed in concrete, Cem. Concr. Res. 102 (2017) 41-47.

[23] G. Geng, Z. Shi, A. Leemann, C. Borca, T. Huthwelker, K. Glazyrin, I. V. Pekov, S. Churakov, B. Lothenbach, R. Dähn, E. Wieland, Atomistic structure of alkali-silica reaction products refined from X-ray diffraction and micro X-ray absorption data, Cem. Concr. Res. (2019) submitted.

[24] D.A. Kulik, Improving the structural consistency of CSH solid solution thermodynamic models, Cem. Concr. Res. 41 (2011) 477-495. 
[25] R.J. Myers, J.L. Provis, B. Lothenbach, Composition-solubility-structure relationships in calcium (alkali) aluminosilicate hydrate (C-(N, K-) ASH), Dalt. Trans. 44 (2015) $13530-13544$.

[26] T. Kim, J. Olek, Chemical Sequence and Kinetics of Alkali-Silica Reaction Part II. A Thermodynamic Model, J. Am. Ceram. Soc. 97 (2014) 2204-2212.

[27] G.D. Guthrie, J.W. Carey, A thermodynamic and kinetic model for paste-aggregate interactions and the alkali-silica reaction, Cem. Concr. Res. 76 (2015) 107-120.

[28] I. V Pekov, N. V Zubkova, Y.E. Filinchuk, N. V Chukanov, A.E. Zadov, D.Y. Pushcharovsky, E.R. Gobechiya, Shlykovite $\mathrm{KCa}\left[\mathrm{Si}_{4} \mathrm{O}_{9}(\mathrm{OH})\right] \cdot 3 \mathrm{H}_{2} \mathrm{O}$ and cryptophyllite $\mathrm{K}_{2} \mathrm{Ca}\left[\mathrm{Si}_{4} \mathrm{O}_{10}\right] \cdot 5 \mathrm{H}_{2} \mathrm{O}$, new mineral species from the Khibiny alkaline pluton, Kola peninsula, Russia, Geol. Ore Depos. 52 (2010) 767-777.

[29] B. Traynor, H. Uvegi, E. Olivetti, B. Lothenbach, R.. Myers, Methodology for pH measurement in high alkali cementitious systems, Cem. Concr. Res. (2019) submitted.

[30] D.A. Kulik, T. Wagner, S. V Dmytrieva, G. Kosakowski, F.F. Hingerl, K. V Chudnenko, U.R. Berner, GEM-Selektor geochemical modeling package: revised algorithm and GEMS3K numerical kernel for coupled simulation codes, Comput. Geosci. 17 (2013) 1-24.

[31] T. Wagner, D.A. Kulik, F.F. Hingerl, S. V Dmytrieva, GEM-Selektor geochemical modeling package: TSolMod library and data interface for multicomponent phase models, Can. Mineral. 50 (2012) 1173-1195.

[32] T. Thoenen, W. Hummel, U. Berner, E. Curti, The PSI/Nagra Chemical Thermodynamic Database 12/07, PSI report 14-04, Villigen PSI, Switzerland, (2014).

[33] B. Lothenbach, D.A. Kulik, T. Matschei, M. Balonis, L. Baquerizo, B. Dilnesa, G.D. Miron, R.J. Myers, Cemdata18: A chemical thermodynamic database for hydrated Portland cements and alkali-activated materials, Cem. Concr. Res. 115 (2019) 472-506.

[34] R.J. Myers, S.A. Bernal, J.L. Provis, A thermodynamic model for C-(N-) ASH gel: CNASH_ss. Derivation and validation, Cem. Concr. Res. 66 (2014) 27-47.

[35] B.J. Merkel, B. Planer-Friedrich, D.K. Nordstrom, Groundwater geochemistry, A Pract. Guid. to Model. Nat. Contam. Aquat. Syst. 2 (2005).

[36] Z. Shi, B. Lothenbach, The combined effect of potassium, sodium and calcium on alkali-silica reaction products, Cem. Concr. Res. (2019) submitted. 
523 [37] J.W. Bullard, G.W. Scherer, An ideal solid solution model for C-S-H, J. Am. Ceram. Soc. 99 (2016) 4137-4145.

[38] B. Lothenbach, A. Nonat, Calcium silicate hydrates: Solid and liquid phase composition, Cem. Concr. Res. 78 (2015) 57-70.

527

[39] E. L'Hôpital, B. Lothenbach, K. Scrivener, D.A. Kulik, Alkali uptake in calcium alumina silicate hydrate (CASH), Cem. Concr. Res. 85 (2016) 122-136. 
Table 1. Starting materials and mix proportions for the samples.

\begin{tabular}{|c|c|c|c|c|c|c|c|c|c|}
\hline \multirow{2}{*}{ Samples } & $\mathrm{SiO}_{2}(\mathrm{am})$ & $\mathrm{CaO}$ & $\mathrm{KOH}$ & $\mathrm{NaOH}$ & $\mathrm{H}_{2} \mathrm{O}^{\mathrm{a}}$ & \multirow{2}{*}{$\begin{array}{l}\text { water/solid } \\
\mathrm{g} / \mathrm{g}\end{array}$} & $\mathrm{Ca} / \mathrm{Si}$ & $\mathrm{Na}(\mathrm{K}) / \mathrm{Si}$ & $\mathrm{Ca} / \mathrm{Na}(\mathrm{K})$ \\
\hline & $\mathrm{g}$ & $\mathrm{g}$ & $\mathrm{g}$ & $\mathrm{g}$ & $\mathrm{g}$ & & \multicolumn{3}{|c|}{$\mathrm{mol} / \mathrm{mol}$} \\
\hline \multicolumn{10}{|c|}{$\mathrm{CaO}-\mathrm{SiO}_{2}-\mathrm{K}_{2} \mathrm{O}$ with higher(lower) water contents } \\
\hline $\mathrm{SKC}_{0}$ & 4 & 0 & 1.87 & & 60 & 10.2 & 0 & 0.5 & 0 \\
\hline $\mathrm{SKC}_{0.1}$ & 4 & 0.373 & 1.87 & & $60(30)$ & $9.6(4.8)$ & 0.1 & 0.5 & 0.2 \\
\hline $\mathrm{SKC}_{0.2}$ & 4 & 0.747 & 1.87 & & $60(30)$ & $9.1(4.5)$ & 0.2 & 0.5 & 0.4 \\
\hline $\mathrm{SKC}_{0.3}$ & 4 & 1.12 & 1.87 & & $60(30)$ & $8.6(4.3)$ & 0.3 & 0.5 & 0.6 \\
\hline $\mathrm{SKC}_{0.4}$ & 4 & 1.49 & 1.87 & & $80(40)$ & $10.9(5.4)$ & 0.4 & 0.5 & 0.8 \\
\hline $\mathrm{SKC}_{0.5}$ & 4 & 1.867 & 1.87 & & $100(50)$ & $12.9(6.5)$ & 0.5 & 0.5 & 1 \\
\hline \multicolumn{10}{|c|}{$\mathrm{CaO}-\mathrm{SiO}_{2}-\mathrm{Na}_{2} \mathrm{O}$ with only high water contents } \\
\hline $\mathrm{SNC}_{0}$ & 4 & 0 & & 1.33 & 60 & 11.3 & 0 & 0.5 & 0 \\
\hline $\mathrm{SNC}_{0.1}$ & 4 & 0.373 & & 1.33 & 60 & 10.5 & 0.1 & 0.5 & 0.2 \\
\hline $\mathrm{SNC}_{0.2}$ & 4 & 0.747 & & 1.33 & 60 & 9.9 & 0.2 & 0.5 & 0.4 \\
\hline $\mathrm{SNC}_{0.3}$ & 4 & 1.12 & & 1.33 & 60 & 9.3 & 0.3 & 0.5 & 0.6 \\
\hline $\mathrm{SNC}_{0.4}$ & 4 & 1.49 & & 1.33 & 100 & 14.7 & 0.4 & 0.5 & 0.8 \\
\hline $\mathrm{SNC}_{0.5}$ & 4 & 1.867 & & 1.33 & 100 & 13.9 & 0.5 & 0.5 & 1 \\
\hline
\end{tabular}

${ }^{a}$ For the K-containing samples, high $(60-100)$ and low $(30-50)$ water contents were applied during mixing. 
Table 2. Standard thermodynamic properties at $25^{\circ} \mathrm{C}$ and $1 \mathrm{~atm}$ for the $\mathrm{C}-(\mathrm{N}-) \mathrm{K}-\mathrm{S}-\mathrm{H}$ solid solution.

\begin{tabular}{llllllll}
\hline & $\log _{10} \mathrm{~K}_{\mathrm{S0}}{ }^{\mathrm{a}}$ & $\begin{array}{l}\Delta_{\mathrm{f}} \mathrm{G}^{\circ} \\
{[\mathrm{kJ} / \mathrm{mol}]}\end{array}$ & $\begin{array}{l}\Delta_{\mathrm{f}} \mathrm{H}^{\circ} \\
{[\mathrm{kJ} / \mathrm{mol}]}\end{array}$ & $\begin{array}{l}\mathrm{S}^{\circ} \\
{[\mathrm{J} / \mathrm{K} / \mathrm{mol}]}\end{array}$ & $\begin{array}{l}\mathrm{C}_{\mathrm{p}}^{\circ} \\
{[\mathrm{J} / \mathrm{K} / \mathrm{mol}]}\end{array}$ & $\begin{array}{l}\mathrm{V}^{\circ} \\
{\left[\mathrm{cm}^{3} / \mathrm{mol}\right]}\end{array}$ & $\mathrm{Ref}$ \\
\hline $\mathrm{T}_{2} \mathrm{C}^{*}: \mathrm{C}_{3 / 2} \mathrm{~S}_{1} \mathrm{H}_{5 / 2}$ & -11.6 & -2465.4 & -2720.7 & 167 & 237 & 80.6 & {$[34]$} \\
T5C $^{*}: \mathrm{C}_{5 / 4} \mathrm{~S}_{5 / 4} \mathrm{H}_{5 / 2}$ & -10.5 & -2516.9 & -2780.3 & 159.9 & 234.1 & 79.3 & {$[34]$} \\
TobH ${ }^{*}: \mathrm{C}_{1} \mathrm{~S}_{3 / 2} \mathrm{H}_{5 / 2}$ & -7.9 & -2560 & -2831.4 & 152.8 & 231.2 & 85 & {$[34]$} \\
INFCN: $\mathrm{C}_{1} \mathrm{~N}_{5 / 16} \mathrm{~S}_{3 / 2} \mathrm{H}_{19 / 16}$ & -10.7 & -2452.5 & -2642.5 & 185.6 & 183.7 & 71.1 & {$[34]$} \\
INFCK: $\mathrm{C}_{1} \mathrm{~K}_{5 / 16} \mathrm{~S}_{3 / 2} \mathrm{H}_{19 / 16}$ & -11.2 & -2468.2 & -2652.2 & 212.2 & 165.1 & 77.5 & this study \\
\hline
\end{tabular}

${ }^{a}$ The solubility products refer to the solubility with respect to the species $\mathrm{SiO}(\mathrm{OH})_{3}{ }_{3}, \mathrm{OH}^{-}, \mathrm{H}_{2} \mathrm{O}, \mathrm{Ca}^{2+}, \mathrm{K}^{+}, \mathrm{Na}^{+}$.

Table 3. Chemical compositions (molar ratio) obtained from SEM/EDX and mass balance for the synthesized ASR products.

\begin{tabular}{|c|c|c|c|c|c|c|c|c|c|c|c|}
\hline \multirow{2}{*}{ Sample $^{\text {a }}$} & \multirow{2}{*}{ ASR products } & \multicolumn{3}{|c|}{ Selected values for GEMS } & \multicolumn{3}{|l|}{ SEM/EDX } & \multicolumn{3}{|c|}{ Mass balance } & \multirow{2}{*}{$\frac{\mathrm{TGA}^{\mathrm{c}}}{\mathrm{H}_{2} \mathrm{O} / \mathrm{Si}}$} \\
\hline & & $\mathrm{Ca} / \mathrm{Si}$ & $\mathrm{Na}($ or $\mathrm{K}) / \mathrm{Si}$ & $\mathrm{H}_{2} \mathrm{O} / \mathrm{Si}$ & $\mathrm{Ca} / \mathrm{Si}$ & $\mathrm{K} / \mathrm{Si}$ & $\mathrm{Na} / \mathrm{Si}$ & $\mathrm{Ca} / \mathrm{Si}$ & $\mathrm{K} / \mathrm{Si}$ & $\mathrm{Na} / \mathrm{Si}$ & \\
\hline $\mathrm{SNC}$ & Na-shlykovite & 0.25 & 0.25 & 0.95 & - & - & - & 0.29 & - & 0.35 & 0.95 \\
\hline $\mathrm{SK}_{0.35} \mathrm{~N}_{0.15} \mathrm{C}$ & ASR-P1 & 0.29 & 0.13 & 0.73 & $0.29 \pm 0.01$ & $0.13 \pm 0.02$ & $0.01 \pm 0.01$ & 0.32 & 0.29 & 0.10 & 0.73 \\
\hline SKC & K-shlykovite & $0.25^{\mathrm{b}}$ & $0.25^{\mathrm{b}}$ & $0.875^{b}$ & $0.23 \pm 0.01$ & $0.22 \pm 0.03$ & - & 0.30 & 0.41 & - & 0.78 \\
\hline
\end{tabular}

$538{ }^{a}$ The labelling of the samples $\mathrm{SNC}, \mathrm{SKC}$ and $\mathrm{SK}_{0.35} \mathrm{~N}_{0.15} \mathrm{C}$ are the same as those in the previous study, where $\mathrm{S}, \mathrm{N}, \mathrm{K}$, and $\mathrm{C}$

539 stands for $\mathrm{Si}, \mathrm{Na}, \mathrm{K}$ and $\mathrm{Ca}$, respectively.

$540{ }^{\mathrm{b}}$ Chemical composition of K-shlykovite was reported in [28]. The same Ca/Si and alkali/Si is applied to Na-shlykovite con-

541 sidering the simple alkali substitution of shlykovite [8].

$542 \quad{ }^{\mathrm{c}} \mathrm{H}_{2} \mathrm{O} / \mathrm{Si}$ ratios was measured by TGA from [8]. 
Table 4. Solubility products at $80{ }^{\circ} \mathrm{C}$ obtained from over- and under-saturation experiments

546 for the three synthesized ASR products. Oversaturation: direct synthesis for 3 month equilib-

547 rium time [8]. Under-saturation: re-dissolved solids for 1 month equilibration time.

\begin{tabular}{|c|c|c|c|c|c|c|c|c|}
\hline & $\mathrm{Si}$ & $\mathrm{Na}$ & $\mathrm{K}$ & $\mathrm{Ca}$ & $\mathrm{pH}^{\mathrm{b}}$ & & $\log _{10} \mathrm{~K}_{\mathrm{S} 0,80^{\circ} \mathrm{C}}$ & \\
\hline Sample ${ }^{\mathrm{a}}$ & $\mathrm{mM}$ & $\mathrm{mM}$ & $\mathrm{mM}$ & $\mathrm{mM}$ & $23{ }^{\circ} \mathrm{C} \quad 80{ }^{\circ} \mathrm{C}$ & Phases & Na-shlykovite ASR-P1 & K-shlykovite \\
\hline
\end{tabular}

Precipitation experiments (over-saturation)

$\begin{array}{llllllllll}\mathrm{SNC} & 302 & 402 & - & 0.025 & 12.6 & 11.2 & \text { Na-shlykovite } & -28.3 & \\ \mathrm{SK}_{0.35} \mathrm{~N}_{0.15} \mathrm{C} & 450 & 146 & 243 & 0.029 & 11.9 & 10.4 & \text { ASR-P1 } & -27.6 & \\ \mathrm{SKC} & 315 & - & 303 & 0.012 & 12.1 & 10.7 & \begin{array}{l}\text { K-shlykovite, } \\ \text { ASR-P1 }\end{array} & -28.1 & -28.0\end{array}$

Dissolution experiments (under-saturation)

$\begin{array}{llllllll}\text { SNC } & 38.5 & 50.2 & 0.07 & 0.06 & 11.7 & 10.2 & \begin{array}{l}\text { Na-shlykovite, } \\ \text { C-S-H }\end{array}\end{array}$

$\begin{array}{llllllll}\mathrm{SK}_{0.35} \mathrm{~N}_{0.15} \mathrm{C} & 69 & 32.8 & 44 & 0.02 & 11.5 & 10.1 & \text { ASR-P1 }\end{array}$

$\begin{array}{llllllllll}\text { SKC\# } & 39.5 & 0.7 & 50.8 & 0.06 & 11.0 & 9.5 & \begin{array}{l}\text { K-shlykovite, } \\ \text { ASR-P1 }\end{array} & \mathbf{- 2 5 . 2} & \mathbf{- 2 5 . 8}\end{array}$

$548{ }^{a}$ The labelling of the samples $\left.\mathrm{SNC}, \mathrm{SKC} \#\right)$ and $\mathrm{SK}_{0.35} \mathrm{~N}_{0.15} \mathrm{C}$ are the same as those in the previous study, where $\mathrm{S}, \mathrm{N}, \mathrm{K}$, and

$549 \mathrm{C}$ stands for $\mathrm{Si}, \mathrm{Na}, \mathrm{K}$ and $\mathrm{Ca}$, respectively.

$550{ }^{\mathrm{b}}$ The $\mathrm{pH}$ values have been measured at $23^{\circ} \mathrm{C}$ and corrected for the effect of temperature on measured $\mathrm{pH}$ values by deducing

$551 \quad 1.47 \mathrm{pH}$ units to account for the strong decrease of measured $\mathrm{pH}$ values from 23 to $80{ }^{\circ} \mathrm{C}$ even at constant $\mathrm{OH}^{-}$concentrations.

Table 5. Solubility products (at $80{ }^{\circ} \mathrm{C}$ ) selected for thermodynamic modelling obtained from dissolution experiments for the K- and Na-shlykovite, while for ASR-P1 the mean value from the data obtained in dissolution experiments and in the precipitation experiments with less than $100 \mathrm{mM}$ Si is calculated.

\begin{tabular}{ccc}
\hline Phases & $\log _{10} \mathrm{~K}_{\mathrm{S} 0,80^{\circ} \mathrm{C}}$ & Solubility products refer to: \\
\hline Na-shlykovite & $-26.5 \pm 2.0^{\mathrm{a}}$ & $\mathrm{K}_{\mathrm{S} 0, \mathrm{Na}-\text { shlykovite }}=\left\{\mathrm{Na}^{+}\right\} \cdot\left\{\mathrm{Ca}^{2+}\right\} \cdot\left\{\mathrm{SiO}_{2}^{0}\right\}^{4} \cdot\left\{\mathrm{OH}^{-}\right\}^{3} \cdot\left\{\mathrm{H}_{2} \mathrm{O}\right\}^{2.3}$ \\
ASR-P1 & $-27.1 \pm 1.1^{\mathrm{a}}$ & $\mathrm{K}_{\mathrm{S} 0, \mathrm{ASR}-\mathrm{P} 1}=\left\{\mathrm{K}^{+}\right\}^{0.52} \cdot\left\{\mathrm{Ca}^{2+}\right\}^{1.16} \cdot\left\{\mathrm{SiO}_{2}^{0}\right\}^{4} \cdot\left\{\mathrm{OH}^{-}\right\}^{2.84} \cdot\left\{\mathrm{H}_{2} \mathrm{O}\right\}^{1.5}$ \\
K-shlykovite & $-25.8 \pm 2.0^{\mathrm{a}}$ & $\mathrm{K}_{\mathrm{S} 0, \mathrm{~K}-\text { shlykovite }}=\left\{\mathrm{K}^{+}\right\} \cdot\left\{\mathrm{Ca}^{2+}\right\} \cdot\left\{\mathrm{SiO}_{2}^{0}\right\}^{4} \cdot\left\{\mathrm{OH}^{-}\right\}^{3} \cdot\left\{\mathrm{H}_{2} \mathrm{O}\right\}^{2}$ \\
\hline
\end{tabular}
and Na-shlykovite are roughly estimated. 
Table 6. The measured dissolved concentrations of the K- and Na-containing samples in equi-

562 librium, together with the summary of solid phases observed from XRD, bulk chemical com-

563 positions of the solids calculated from mass balance and derived solubility products at $80{ }^{\circ} \mathrm{C}$

564 of the synthesized K-shlykovite, ASR-P1 and Na-shlykovite.

\begin{tabular}{|c|c|c|c|c|c|c|c|c|c|c|c|c|}
\hline \multirow[b]{2}{*}{ Sample } & \multirow{2}{*}{$\begin{array}{l}\mathrm{Si} \\
\mathrm{mM}\end{array}$} & \multirow{2}{*}{$\frac{\mathrm{K}}{\mathrm{mM}}$} & \multirow{2}{*}{$\frac{\mathrm{Na}}{\mathrm{mM}}$} & \multirow{2}{*}{$\frac{\mathrm{Ca}}{\mathrm{mM}}$} & \multirow{2}{*}{$\begin{array}{l}\mathrm{pH}^{\mathrm{a}} \\
23^{\circ} \mathrm{C}\end{array}$} & \multirow[b]{2}{*}{$80^{\circ} \mathrm{C}$} & \multirow[b]{2}{*}{ Phases } & \multicolumn{2}{|c|}{ Bulk compositions } & \multicolumn{3}{|c|}{$\log _{10} \mathrm{~K}_{\mathrm{S} 080^{\circ} \mathrm{C}}{ }^{\mathrm{b}}$} \\
\hline & & & & & & & & $\begin{array}{l}\mathrm{Ca} / \mathrm{Si} \\
\mathrm{mol} / \mathrm{mol}\end{array}$ & $\begin{array}{l}\mathrm{K} / \mathrm{Si} \\
\mathrm{mol} / \mathrm{mol}\end{array}$ & $\begin{array}{l}\text { K- } \\
\text { shlykovite }\end{array}$ & $\begin{array}{l}\text { ASR- } \\
\text { P1 }\end{array}$ & $\begin{array}{l}\text { Na- } \\
\text { shlykovite }\end{array}$ \\
\hline \multicolumn{13}{|c|}{ K-containing samples with high water contents } \\
\hline $\mathrm{SKC}_{0}$ & 902 & 496 & & $\begin{array}{l}< \\
0.01\end{array}$ & 11.3 & 9.8 & $\mathrm{SiO}_{2}(\mathrm{am})$ & 0 & $0.19 \pm 0.53$ & - & - & \\
\hline $\mathrm{SKC}_{0.2}$ & 401 & 351 & & $\begin{array}{l}< \\
0.01\end{array}$ & 11.6 & 10.2 & ASR-P1, K-shlykovite & $0.31 \pm 0.02$ & $0.26 \pm 0.07$ & $-27.5^{c}$ & $-27.5^{c}$ & \\
\hline $\mathrm{SKC}_{0.3}$ & 135 & 228 & & 0.96 & 12.2 & 10.7 & ASR-P1 & $0.34 \pm 0.01$ & $0.31 \pm 0.03$ & - & $-26.0^{c}$ & \\
\hline $\mathrm{SKC}_{0.4}$ & 12.4 & 134 & & 2.82 & 12.7 & 11.2 & ASR-P1 & $0.40 \pm 0.01$ & $0.33 \pm 0.01$ & - & -27.3 & \\
\hline $\mathrm{SKC}_{0.5}$ & 9.8 & 168 & & 1.24 & 12.9 & 11.4 & ASR-P1, C-S-H & $0.51 \pm 0.01$ & $0.23 \pm 0.03$ & - & -28.0 & \\
\hline \multicolumn{13}{|c|}{ K-containing samples with low water contents } \\
\hline $\mathrm{SKC}_{0.1}$ & 1381 & 744 & & 0.01 & 11.2 & 9.7 & K-shlykovite & $0.25 \pm 0.05$ & $0.39 \pm 0.16$ & $-26.6^{c}$ & - & \\
\hline $\mathrm{SKC}_{0.2}$ & 702 & 510 & & 0.01 & 11.6 & 10.1 & K-shlykovite & $0.29 \pm 0.01$ & $0.37 \pm 0.05$ & $-27.3^{c}$ & - & \\
\hline $\mathrm{SKC}_{0.3}$ & 399 & 421 & & 0.10 & 12.4 & 10.9 & ASR-P1 & $0.36 \pm 0.01$ & $0.36 \pm 0.03$ & - & $-27.5^{c}$ & \\
\hline $\mathrm{SKC}_{0.4}$ & 125 & 255 & & 0.11 & 12.9 & 11.4 & ASR-P1 & $0.43 \pm 0.01$ & $0.34 \pm 0.02$ & - & $-28.2^{c}$ & \\
\hline $\mathrm{SKC}_{0.5}$ & 91.6 & 252 & & 0.15 & 13 & 11.5 & ASR-P1, C-S-H & $0.54 \pm 0.01$ & $0.30 \pm 0.02$ & - & -28.3 & \\
\hline \multicolumn{13}{|c|}{ Na-containing samples with high water contents } \\
\hline $\mathrm{SNC}_{0}$ & 904 & & 543 & 0.04 & 11.2 & 9.7 & $\mathrm{SiO}_{2}(\mathrm{am})$ & 0 & $0.09 \pm 0.47$ & & & - \\
\hline $\mathrm{SNC}_{0.1}$ & 750 & & 478 & 0.02 & 11.2 & 9.7 & Na-shlykovite & $0.31 \pm 0.06$ & $0.23 \pm 0.21$ & & & -26.8 \\
\hline $\mathrm{SNC}_{0.2}$ & 458 & & 374 & 0.02 & 11.5 & 10.1 & Na-shlykovite & $0.34 \pm 0.02$ & $0.27 \pm 0.10$ & & & -27.3 \\
\hline $\mathrm{SNC}_{0.3}$ & 442 & & 382 & 0.07 & 11.7 & 10.2 & Na-shlykovite & $0.50 \pm 0.03$ & $0.27 \pm 0.07$ & & & -26.8 \\
\hline $\mathrm{SNC}_{0.4}$ & 152 & & 171 & 0.05 & 11.9 & 10.5 & Na-shlykovite, C-S-H & $0.52 \pm 0.01$ & $0.32 \pm 0.04$ & & & -27.1 \\
\hline $\mathrm{SNC}_{0.5}$ & 145 & & 183 & 0.05 & 12.2 & 10.8 & C-S-H & $0.64 \pm 0.02$ & $0.29 \pm 0.05$ & & & - \\
\hline
\end{tabular}

${ }^{a}$ The $\mathrm{pH}$ values have been measured at $23^{\circ} \mathrm{C}$ and corrected for the effect of temperature on measured $\mathrm{pH}$ values by deducing

$5661.47 \mathrm{pH}$ units to account for the strong decrease of measured $\mathrm{pH}$ values from $23^{\circ} \mathrm{C}$ to $80^{\circ} \mathrm{C}$ even at constant $\mathrm{OH}^{-}$concentra-

567 tions.

$568 \mathrm{~b}^{\mathrm{b}}$ The solubility product refer to: $\mathrm{K}_{\mathrm{S} 0, \mathrm{~K}-\text { shlykovite }}=\left\{\mathrm{K}^{+}\right\} \cdot\left\{\mathrm{Ca}^{2+}\right\} \cdot\left\{\mathrm{SiO}_{2}^{0}\right\}^{4} \cdot\left\{\mathrm{OH}^{-}\right\}^{3} \cdot\left\{\mathrm{H}_{2} \mathrm{O}\right\}^{2} ; \mathrm{K}_{\mathrm{S} 0, \mathrm{ASR}-\mathrm{P} 1}=\left\{\mathrm{K}^{+}\right\}^{0.52}$.

$569\left\{\mathrm{Ca}^{2+}\right\}^{1.16} \cdot\left\{\mathrm{SiO}_{2}^{0}\right\}^{4} \cdot\left\{\mathrm{OH}^{-}\right\}^{2.84} \cdot\left\{\mathrm{H}_{2} \mathrm{O}\right\}^{1.5} ; \mathrm{K}_{\mathrm{SO}, \mathrm{Na}-\text { shlykovite }}=\left\{\mathrm{Na}^{+}\right\} \cdot\left\{\mathrm{Ca}^{2+}\right\} \cdot\left\{\mathrm{SiO}_{2}^{0}\right\}^{4} \cdot\left\{\mathrm{OH}^{-}\right\}^{3} \cdot\left\{\mathrm{H}_{2} \mathrm{O}\right\}^{2.3}$

$570{ }^{\mathrm{c}}$ At very high total Si concentration, polynuclear Si-species dominate the solution; their speciation and stability at higher

571 temperature is not well known, which associates the obtained solubility products with an increased error. The solubility prod-

572 uct calculated at high Si-concentrations are added for comparison only and not used in the derivation of the suggested solu-

573 bility products for K-shlykovite, Na-shlykovite or ASR-P1. 
(a)
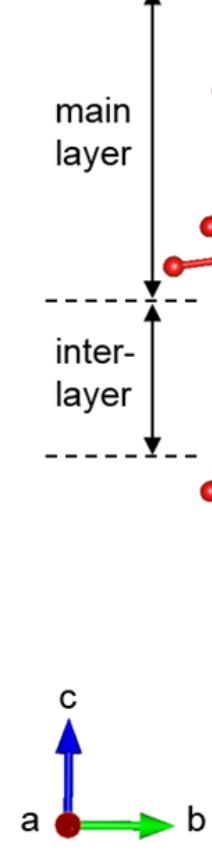

layer

layer

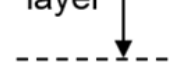

(1)<smiles>O=C1CCCO1</smiles>
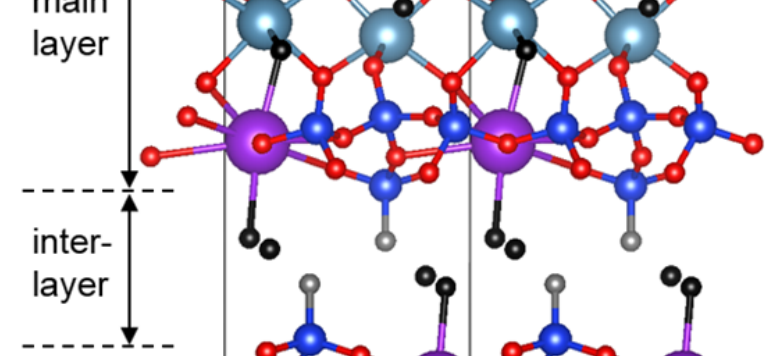

b

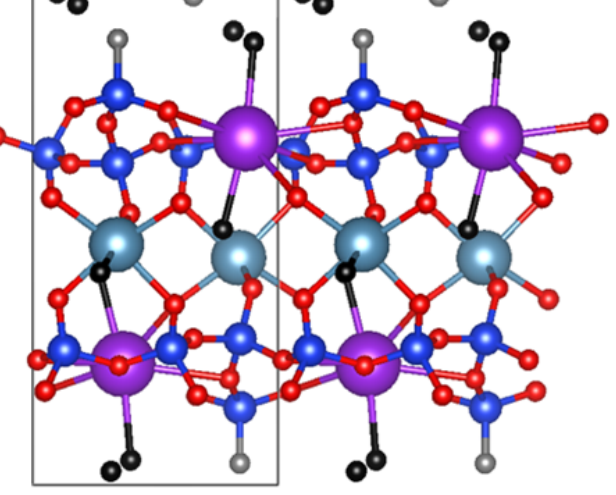

(b)

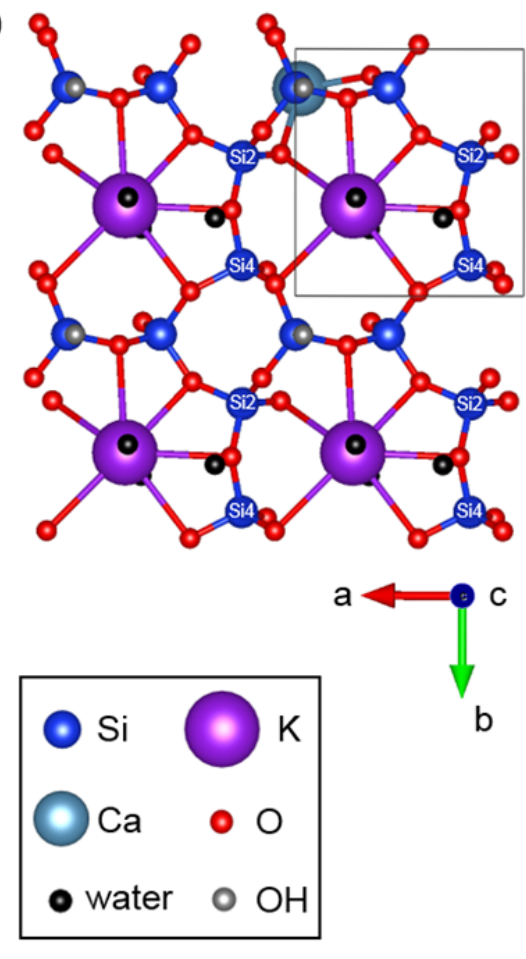

575 Fig. 1. A schematic structure of K-shlykovite: (a) viewed along [100], (b) the potassium sili-

576 cate layer viewed along [001]. Na-shlykovite has similar structure by simply exchange the K

577 with $\mathrm{Na}$ in the silicate ring. Figure reproduced from previous study [8]. 


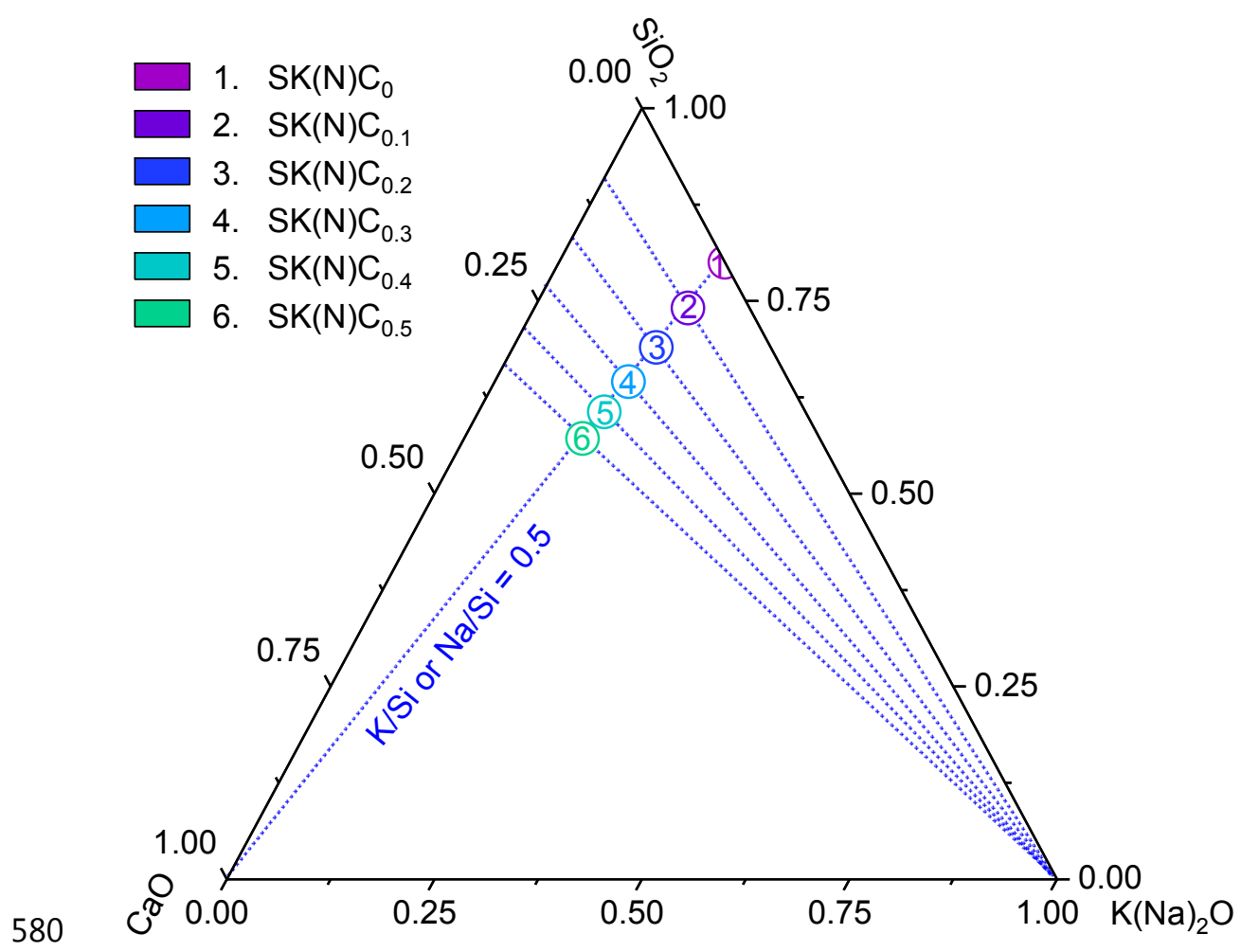

581 Fig. 2. Bulk compositions (molar fraction) of the starting materials for K- and Na-containing 582 samples projected in $\mathrm{CaO}-\mathrm{SiO}_{2}-\mathrm{K}(\text { or } \mathrm{Na})_{2} \mathrm{O}$ ternary diagram. 


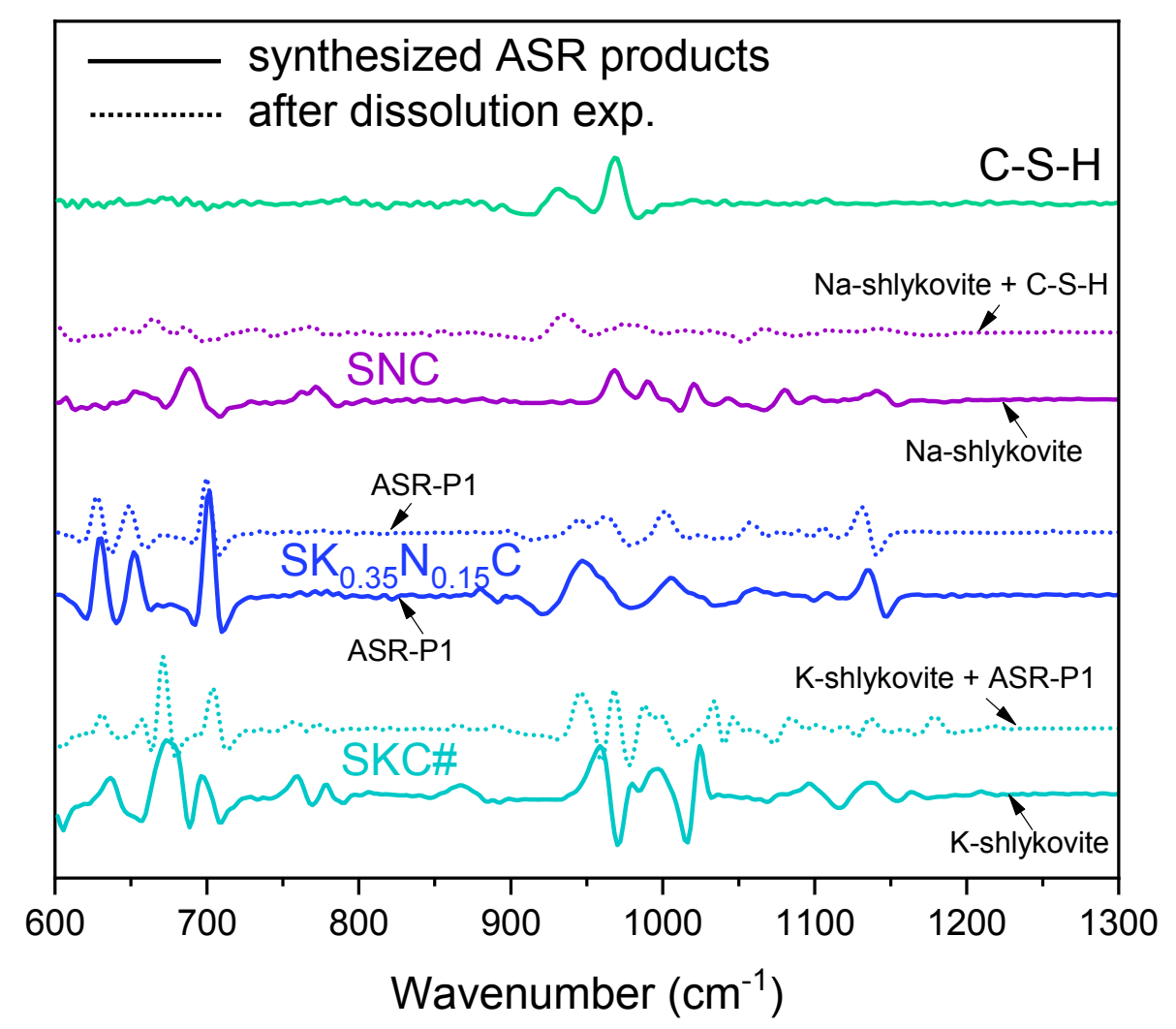

Fig. 3. Second derivative of the FTIR spectra of (a) the directly synthesized ASR products [8], 585 and (b) the solids after re-dispersion of the synthesized ASR products in water. 

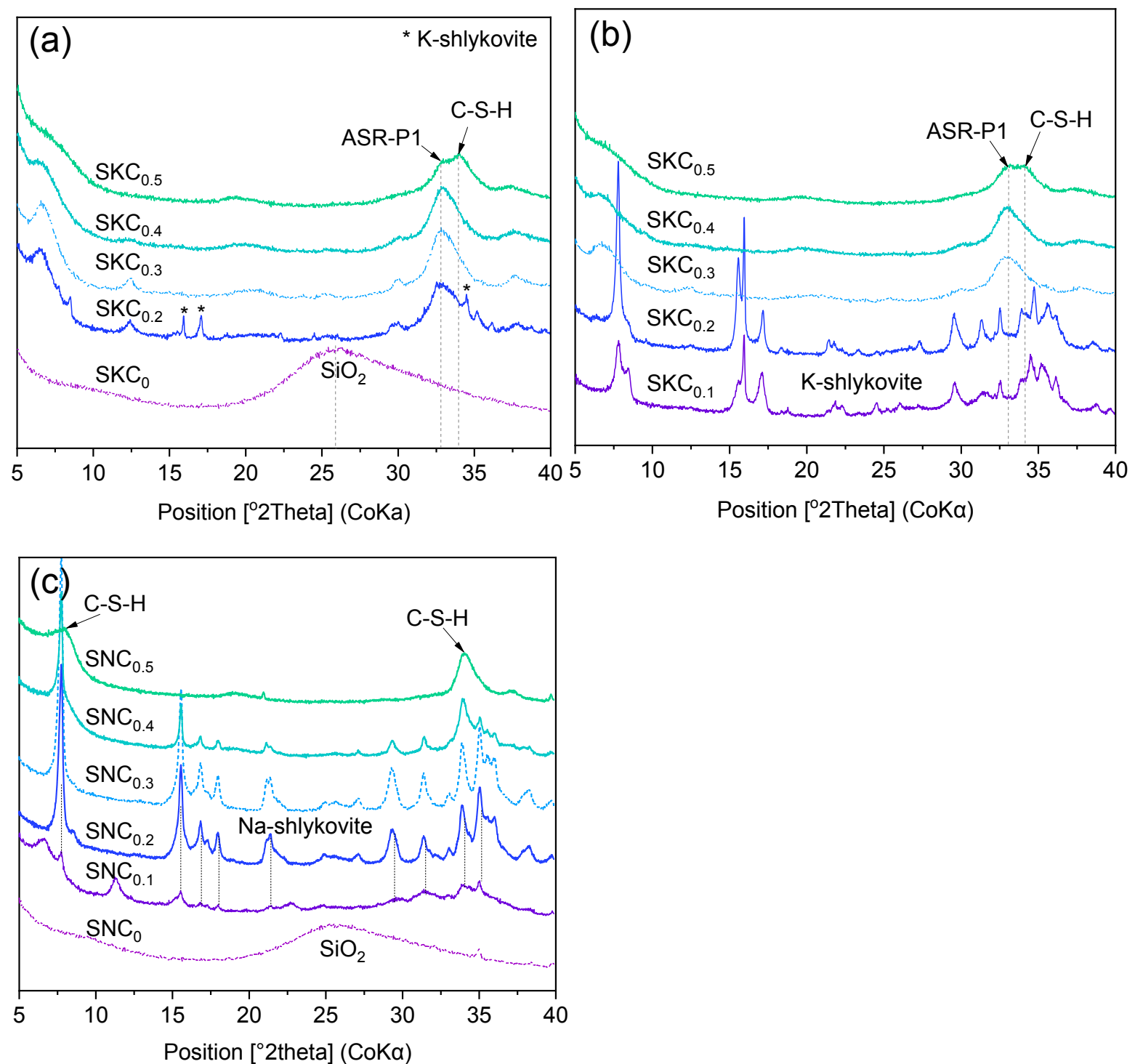

587

Position [ ${ }^{\circ} 2$ theta] (CoKa)

588 Fig. 4. XRD diffractograms of the K-containing samples with (a) high water contents, and (b)

589 low water contents, and (c) for the Na containing samples with high water contents only. The 590 label of the sample e.g. $\mathrm{SKC}_{0.1}$ refer to the sample with $\mathrm{Ca} / \mathrm{Si}$ of 0.1. ASR-P1: an unknown 591 phase reported in [8]. The bottle for the sample $\mathrm{SKC}_{0.1}$ with high water content was broken, thus no measurement was performed. 


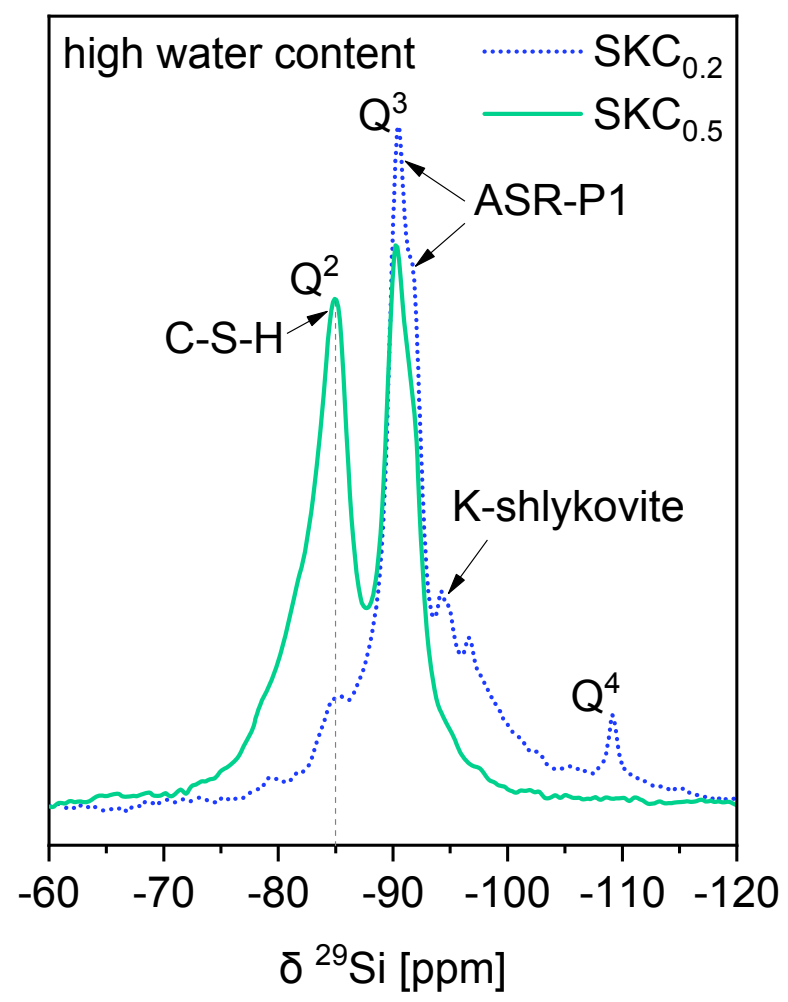

594

595 Fig. $5 .{ }^{29} \mathrm{Si}$ MAS NMR spectra for the $\mathrm{SKC}_{0.2}$ and $\mathrm{SKC}_{0.5}$ samples with high water contents 596 after 90 days of reaction. 

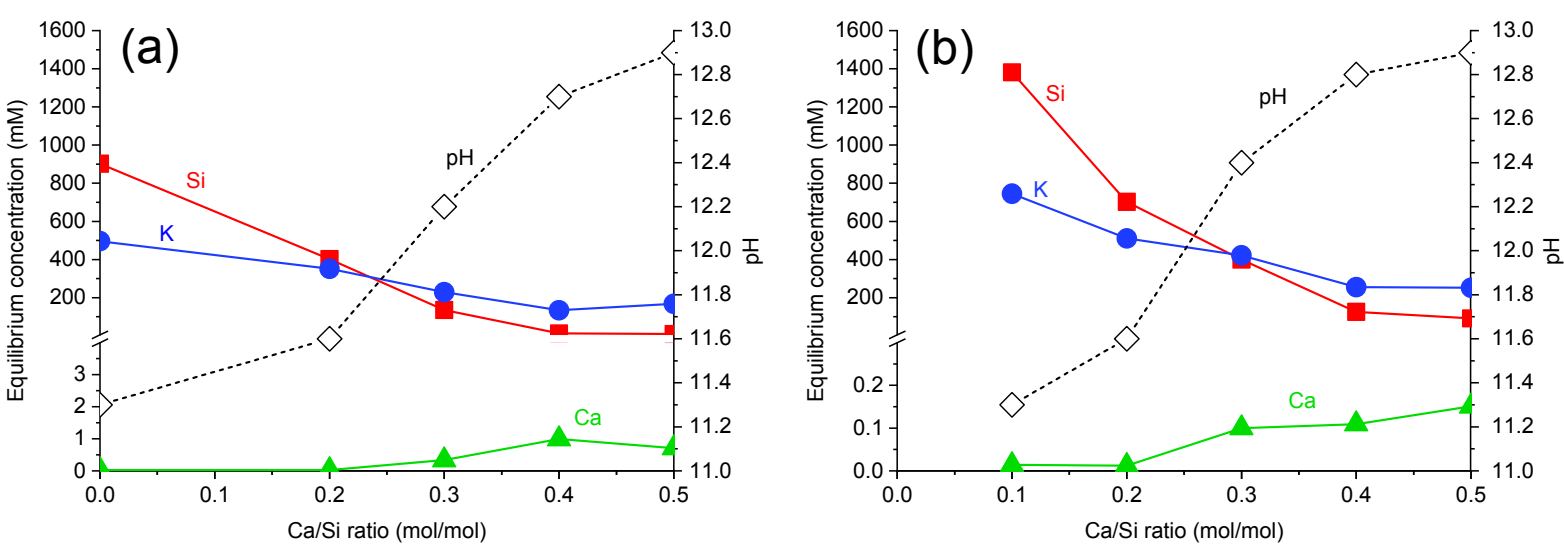

597

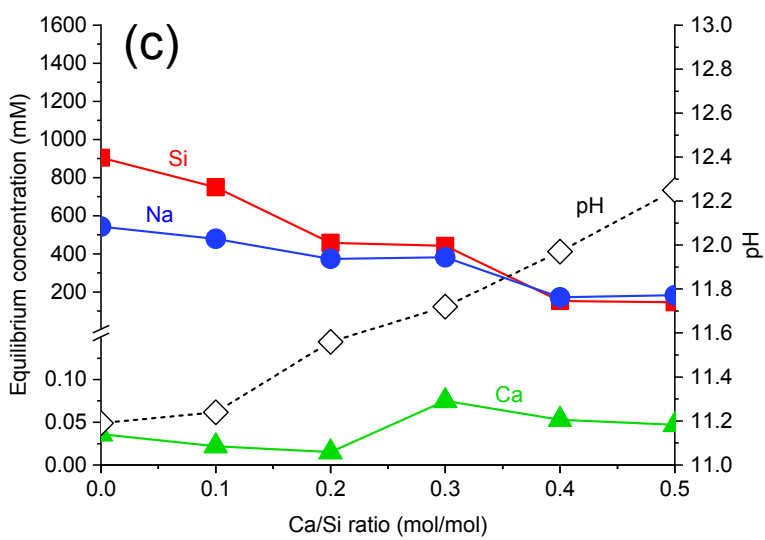

Fig 6. Changes of equilibrium concentrations and the $\mathrm{pH}$ values (measured at $23{ }^{\circ} \mathrm{C}$ ) of the 600 equilibrium solutions for the K-containing samples with (a) high water contents, and (b) low 601 water contents, and (c) for the Na containing samples with high water contents only. 

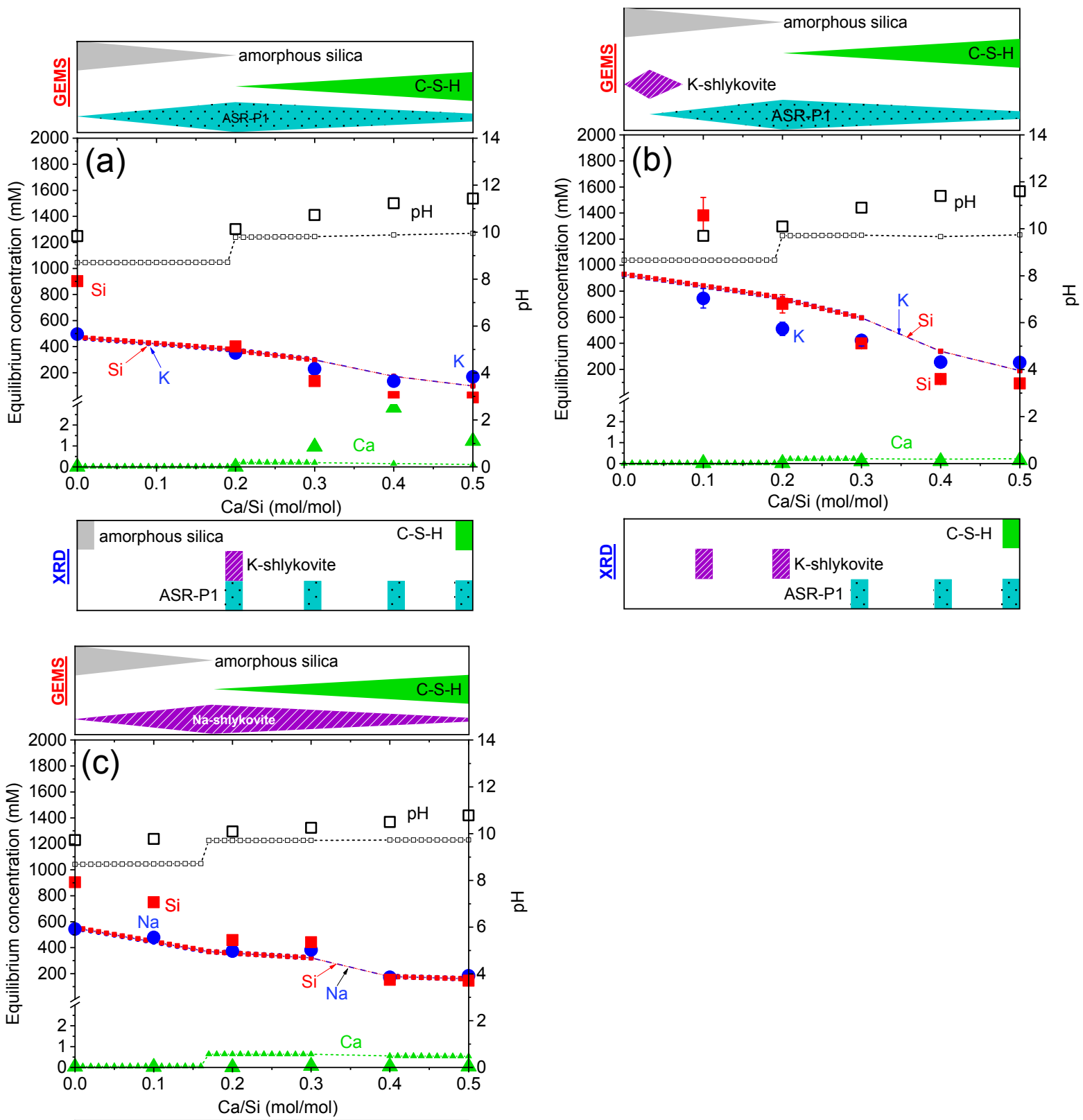
ASR-P1

605 Fig 7. Effect of $\mathrm{Ca} / \mathrm{Si}$ ratio on the solution chemistry and phase assemblages in the $\mathrm{K}$ containing samples with (a) high water contents, and (b) low water contents, and (c) in the

607 Na-containing samples with high water contents only. The small symbols on the dashed lines refer to the results calculated from thermodynamic modelling at $80{ }^{\circ} \mathrm{C}$. The large symbols refer to the measured concentration and corrected $\mathrm{pH}$ values at the same temperature. 


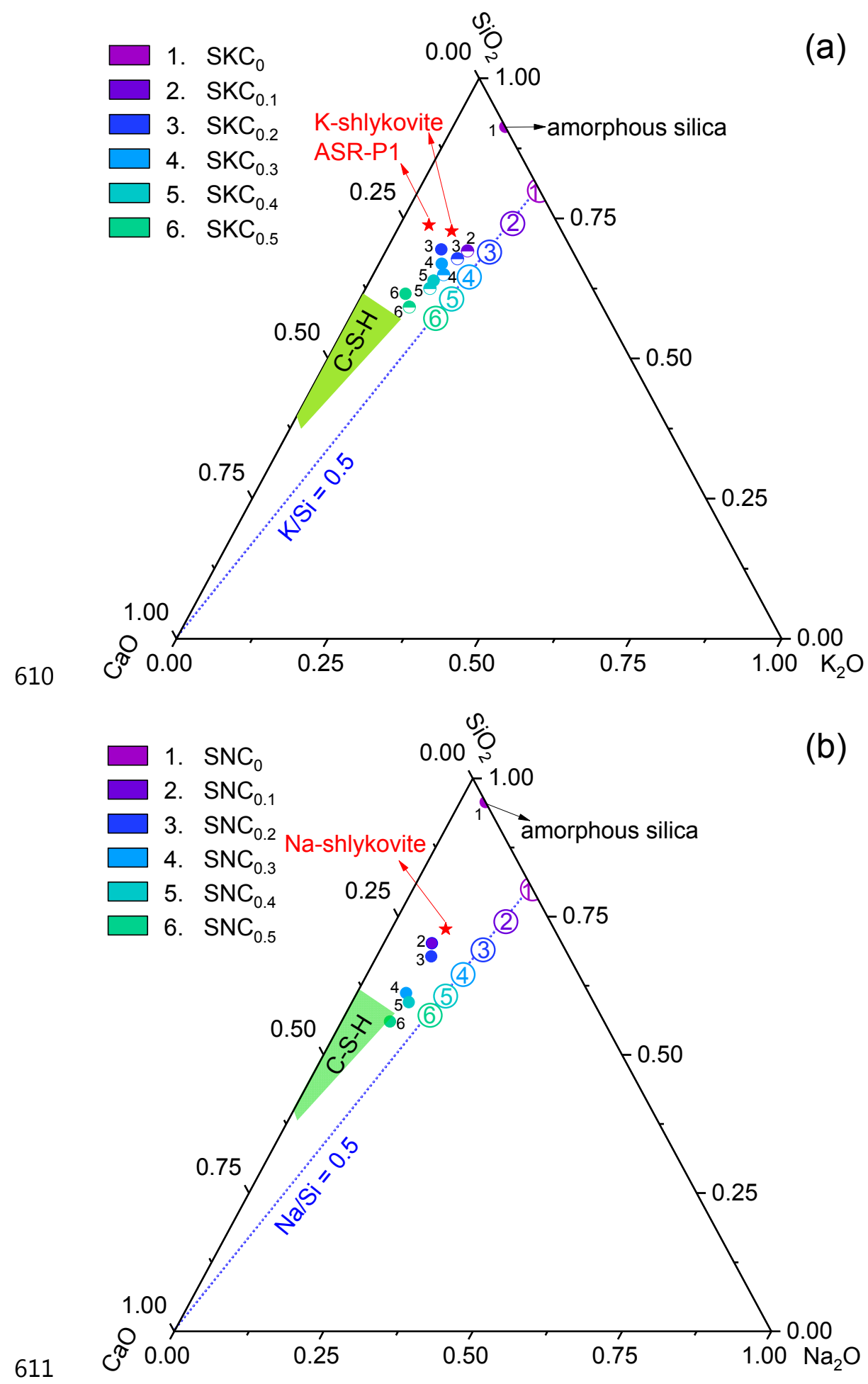

612 Fig 8. Bulk chemical compositions (molar fraction) projected in the ternary diagrams (a)

$613 \mathrm{CaO}-\mathrm{SiO}_{2}-\mathrm{K}_{2} \mathrm{O}$ and (b) $\mathrm{CaO}-\mathrm{SiO}_{2}-\mathrm{Na}_{2} \mathrm{O}$ for the starting materials (empty circle) and the sol614 ids obtained after 90 days of reaction at $80{ }^{\circ} \mathrm{C}$ (filled circle for the $\mathrm{K}$ or Na-containing sam615 ples with high water contents, and half-filled circle for the K samples with low water con616 tents). The chemical compositions for the K-shlykovite, ASR-P1 and Na-shlykovite are 617 indicated by red star in the corresponding diagram. 


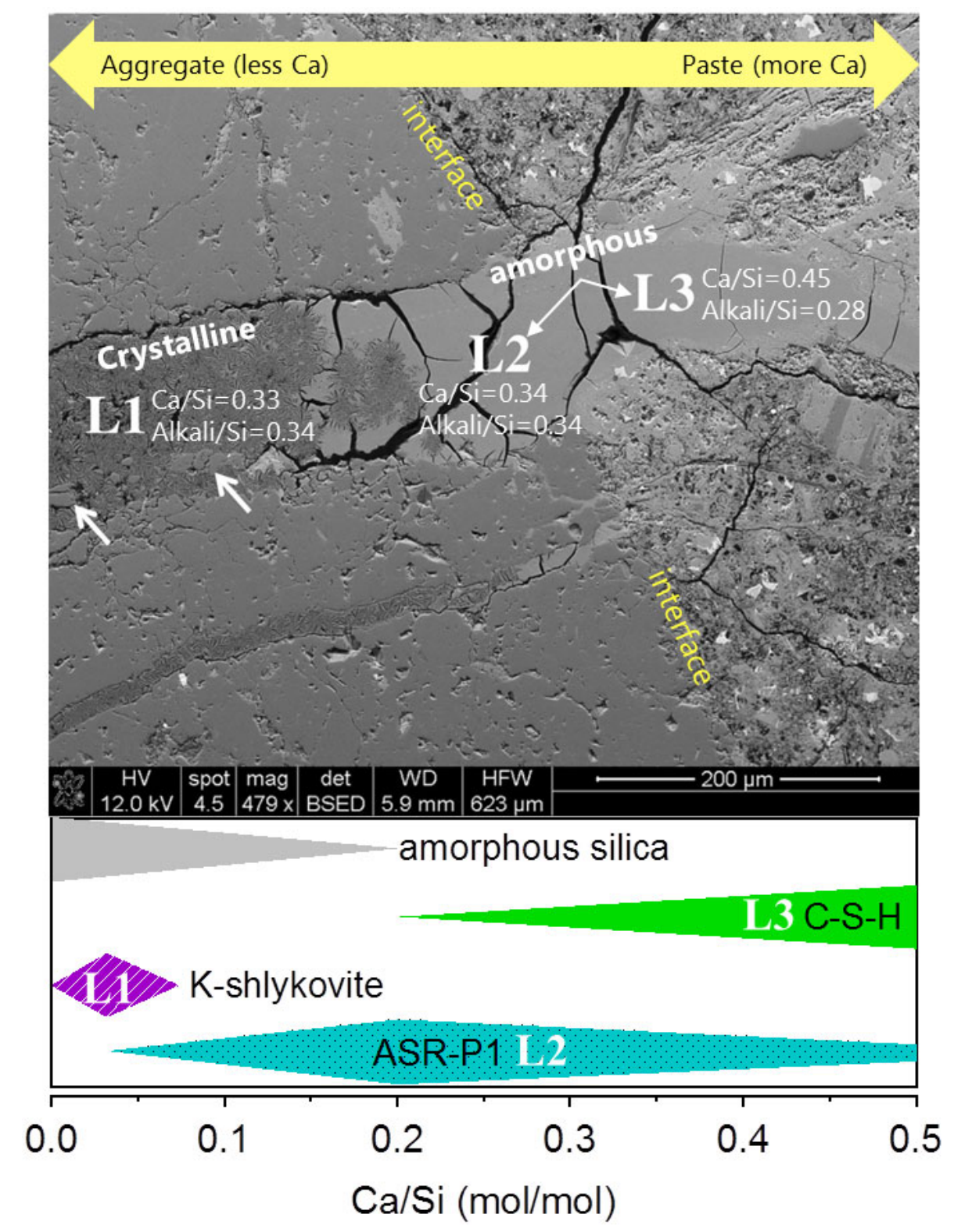

619 Fig 9. Demonstration of the links between concrete and model system with respect of the role 620 of calcium on formation of ASR products. SEM image of ASR affected concrete is repro621 duced using the data from [22], where three different reaction products were identified at 622 three different locations along the vein of aggregate extended to cement paste, i.e., L1: crys623 talline ASR product; L2: amorphous ASR product with similar chemical composition to crys624 talline ASR product; and L3: amorphous reaction product with high $\mathrm{Ca} / \mathrm{Si}$ ratio, which is re625 lated to C-S-H. 


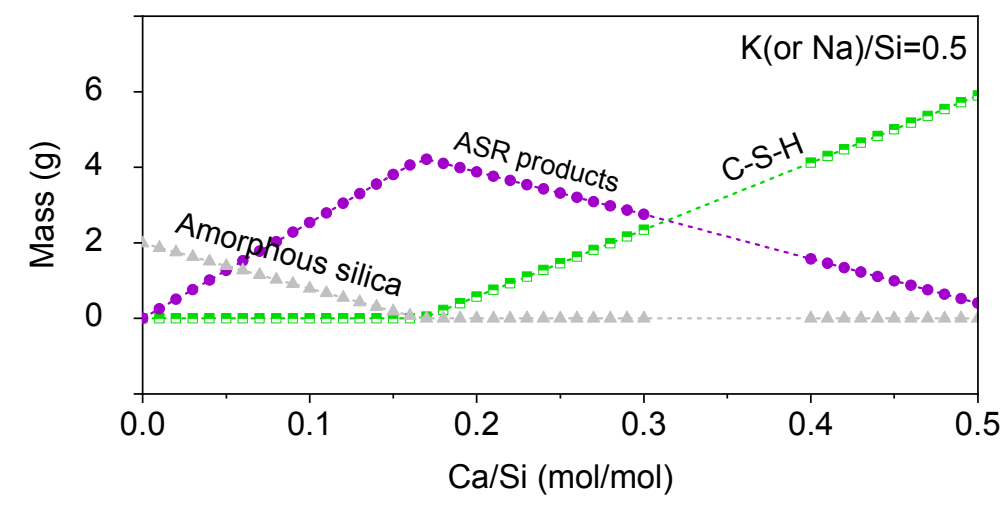

627 Fig 10. Effect of initial $\mathrm{Ca} / \mathrm{Si}$ ratio on the formation of ASR products (ASR-P1/K-shlykovite 628 or Na-shlykovite) in the K- or Na-containing samples at initial $\mathrm{K}$ (or Na)/Si ratio of 0.5 . The 629 symbols on the dashed lines are data calculated from thermodynamic modelling. No calcula630 tions were executed at $\mathrm{Ca} / \mathrm{Si}$ ratio between 0.3 and 0.4 for the Na-containing samples due to 631 the change of water content. 